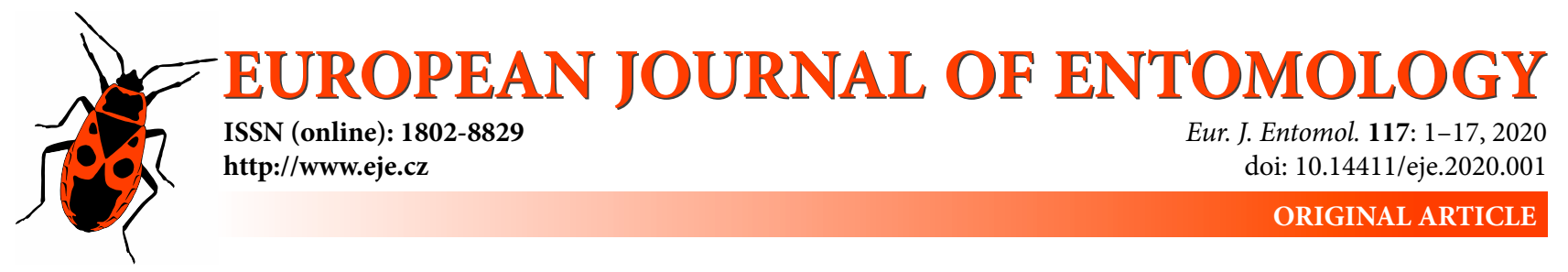

\title{
Oviposition preference maximizes larval survival in the grass-feeding butterfly Melanitis leda (Lepidoptera: Nymphalidae)
}

\author{
Freerk MOLLEMAN ${ }^{1,2}$, SRIDHAR HALALI ${ }^{2,3}$ and ULLASA KODANDARAMAIAH ${ }^{2}$ \\ ${ }^{1}$ Department of Systematic Zoology, Institute of Environmental Biology, Faculty of Biology, A. Mickiewicz University, \\ UI. Uniwersytetu Poznańskiego 9, PL-61-614 Poznań, Poland; e-mail: fremol@amu.edu.pl \\ 2 IISER-TVM Centre for Research and Education in Ecology and Evolution (ICREEE), Indian Institute of Science Education \\ and Research, Thiruvananthapuram, Kerala, 695016, India; e-mails: sridharhalali@gmail.com, Ullasa@iisertvm.ac.in \\ ${ }^{3}$ Department of Zoology, University of Cambridge, Downing Street, Cambridge, CB2 3EJ, UK
}

Key words. Lepidoptera, Nymphalidae, caterpillar, growth rate, larval choice, larval survival, longevity, host plant, oviposition behaviour, polyphagy

\begin{abstract}
Phytophagous insects may be expected to prefer host-plant species on which their larvae perform best, but this has rarely been explored in grass-feeding butterflies. We explored links between oviposition preferences, larval food preferences, and performance (larval survival and development time, pupal mass, and adult longevity) on 18 species of grass in the common evening brown, Melanitis leda L. (Nymphalidae: Melanitini), a tropical butterfly that has been recorded from a large number of species of grass. Melanitis leda oviposited on all of the grass species offered in choice experiments, and larvae were able to develop to the adult stage on almost all of them. Oviposition preferences were for species of plants on which larval survival was higher, but were not correlated with larval development. The mother's choice of host plant appeared to affect performance of the resulting adults as large butterflies had longer life spans. Ovipositing females appeared to adjust clutch size and position of their eggs on a plant depending on plant traits. Larval survival was only marginally correlated with larval growth rate on the different species of plants. Larvae showed host-plant preferences that were not correlated with adult oviposition preferences, larval survival, or larval growth. Overall, while $M$. leda can utilize a large number of species of grass, it shows marked oviposition preferences. Apparent fine-tuning of clutch size and positioning of eggs on plants with different traits might be another adaptation associated with using a large number of species of plants. We conclude that this grass feeding butterfly selects oviposition sites that maximize the chances of their larvae surviving.
\end{abstract}

\section{INTRODUCTION}

The study of interactions between phytophagous insects and plants is important for understanding global biodiversity and ecosystem functioning (Ehrlich \& Raven, 1964; Gilbert, 1979; Vialatte et al., 2010; Davis et al., 2013). While phytophagous insects range from specialists that feed on a single species of host-plant (monophagous) to generalists that can feed on members of several plant families (polyphagous), most species, including generalists, have host-plant preferences and a performance hierarchy (Gripenberg et al., 2010). Phytophagous insects are presumed to be under selection to evolve suites of traits that promote the matching of preference and performance (Gripenberg et al., 2010). For example, adults are presumed to be selected to prefer laying eggs on plants on which their larvae perform better than on other available plants (Jaenike, 1978; Singer, 1986). Because monophagy and polyphagy each pose different challenges to a phytophagous insect, such as, dealing with plant defences and finding particular species in diverse vegetation (Beaver, 1979), the degree of host-plant specialization will be an important determinant of traits involved in insect-plant interactions (Gripenberg et al., 2010, Schäpers et al., 2016).

Oviposition preferences tend to be under strong selection in the wild because performance of larvae (Singer, 2004) and resulting adults (Scheirs et al., 2000) tends to vary greatly on the different species of plants on which the larvae develop. Indeed, experimental studies indicate a general congruence between oviposition preferences and larval performance (Thompson, 1988; Friberg \& Wiklund, 2009; Gripenberg et al., 2010). However, oviposition preferences are not always strongly correlated with particular measures of larval performance, especially in host-plant generalists (Gripenberg et al., 2010). This is perhaps in part because host-plant generalists are under selection to make oviposition decisions that are adaptive over a wide range of host-plant species, and thus may use oviposition cues that are not optimal for each particular potential host. While more specialized dicotyledonous plant feeders often use particular chemicals that are characteristic of particu- 
lar plant taxa to identify hosts (Renwick \& Chew, 1994), host-plant generalists and grass feeding insects are thought to be more likely to use cues that are indicative of physical defences and nutritional quality (Bernays et al., 2004; Lindman et al., 2013).

Phytophagous insects do not only need to choose on which plant to lay eggs, but also need to select a location on the plant and the size of each clutch (Godfray, 1986; Tscharntke, 1988; Sahoo \& Kodandaramaiah, 2018). For instance, competition might be stronger on small leaves, and therefore females may choose to lay smaller clutches on small leaves (Sahoo \& Kodandaramaiah, 2018). Plant traits such as overall size, leaf size, and plant architecture will differ more among host plants for polyphagous species of insects. Therefore, insect species utilizing many species of plants may be particularly likely to plastically modulate their oviposition behaviour to fit plant traits.

In vegetation where larvae can easily move between plants, such as in grassland, larvae may have considerable freedom to select host plants (Bergman, 2000). Therefore, larvae can also be under selection for preferring optimal host-plants (Wiklund, 1975; Chew, 1980; Bernays et al., 2004; Soler et al., 2012; Gamberale-Stille et al., 2014). If plants differ in overall suitability to larvae, then one would expect that plants that support a higher larval growth rate would also be the ones on which there is better larval survival (Williams, 1999). If this is the case, large larvae would prefer the same plants that they did when they were young. However, because young larvae are especially vulnerable to plant defences (Zalucki et al., 2002), whereas most of the body mass gain occurs in large larvae, the optimal plant species may change as larvae grow (Simpson \& Raubenheimer, 2012). In particular, small larvae may be selected to prefer plants on which survival is highest, and large larvae to prefer plants on which their growth rate is highest.

Many grass-feeding insects are considered to be hostplant generalists in that they can use many species of grass (Wiklund, 1984). However, the host-plant relationships of grass-feeding insects are relatively poorly known (Thomas, 1984; Whitcomb et al., 1987), with the notable exception of agricultural pests such as stem borers of important crops (Leniaud et al., 2006; Showler \& Moran, 2014). Grasses first evolved in forests and are now an abundant element in most types of vegetation, especially in open landscapes (Willis \& McElwain, 2002; Edwards et al., 2010). The radiations of grass-feeding insects are associated with the expansion of grasslands (Peña \& Wahlberg, 2008; Sahoo et al., 2017), which may in part be caused by these insects adapting to the defences of these plants (van Bergen et al., 2016). Grass species differ in nutritional value, so that some species may not provide adequate nutrition for butterfly larvae or support only low growth rates (Mattson, 1980, Barbehenn \& Bernays, 1992; Scheirs et al., 2002). Grasses are considered to rely primarily on physical defences (silicon crystals, coarse fibres, hairs) and fast regrowth, rather than on chemical defences (Cayssi- als \& Rodríguez, 2013; Hartley \& DeGabriel, 2016; Karban \& Takabayashi, 2019; Solofondranohatra et al., 2018). Nevertheless, grasses can be chemically defended and usually have endophytic fungi that can produce defensive chemicals such as alkaloids (Hardy et al., 1985; Faeth \& Bultman, 2002). These differences will lead to differences in insect performance, and are thus expected to select for oviposition preferences and ultimately host-plant specialization in grass-feeding insects.

Butterflies are especially popular model systems for exploring interactions between phytophagous insects and their host plants, both at a macro-evolutionary scale and in detailed case studies. However, species of satyrine butterflies (Nymphalidae: Satyrinae) are often simply regarded as "grass-feeding" (Larsen, 2005; Kunte, 2012) and detailed information on their host-plant use is often lacking (García-Barros \& Fartmann, 2009). While many species of satyrine butterflies can use many grass species, some are more specialized, indicating that selection for specialization can be strong in grass-feeders (Bergman, 2000; García-Barros \& Fartmann, 2009). Examples of specialized Melanitini include the Great Evening Brown Melanitis zitenius Herbst 1796 on particular species of bamboo and the Travancore Evening Brown Parantirrhoea marshalli Wood-Mason, 1880 on Ochlandra species (Kalesh \& Prakash, 2009; Kunte, 2012). However, oviposition preferences, larval performance, and links between preference and performance are relatively poorly documented in grass-feeding butterflies (Karlsson \& Wiklund, 1985; Bergman, 2000; Lindman et al., 2013, Stuhldreher \& Fartmann, 2015), especially in the tropics (Moore, 1986; Nokelainen et al., 2016).

We explored links between host-plant preferences and performance of larvae of the Common Evening Brown Melanitis leda L. 1758 (Nymphalidae: Satyrinae). This medium-sized butterfly occurs throughout the tropics except in the Americas, in habitats ranging from dense forest to grassland (Larsen, 2005; Kunte, 2012). It is reported as feeding on a large number of species of grass (Larsen, 2005; Kalesh \& Prakash, 2007). This species has several generations per year, with striking seasonal phenotypic plasticity in colouration and wing-shape (Brakefield, 1987). Therefore, throughout the year, ovipositing females of such multi-voltine species have to choose among grasses with very different properties, and larvae need to be able to deal with the seasonal variation in food quality (Scheirs et al., 2002).

We address (1) to what extent $M$. leda is a host-plant generalist, (2) whether its females prefer to oviposit on plants on which their larvae perform best, (3) whether females vary clutch size and the positioning of eggs on plants of different species, (4) if larvae survive better on plants on which they grow fastest, (5) if larvae prefer species of plants that are preferred by ovipositing females or on which their larvae perform best, and (6) how the species of host-plant on which an individual develops might affect adult longevity. 


\section{MATERIAL AND METHODS Oviposition experiment}

About 30 female M. leda were caught in Thiruvananthapuram, Kerala, India and their eggs were hatched and the larvae reared to the adult stage for use in our experiments over a six-month period. Adults were maintained under outdoor conditions in cages $2.2 \mathrm{~m}$ in height width and length $\left(10.6 \mathrm{~m}^{3}\right)$ and fed banana. Maize (Zea mays L.) seedlings were used to rear larvae in small cages. To obtain plants for oviposition preference tests, maize was grown from seeds in 0.51 pots in compost mixed with soil. Wild grasses that were common and varied widely in plant architecture and habitat were dug up and planted in the same compost-soil mixture as the maize, using the same or larger pots as necessary. Plants were kept outdoors and shade-species were provided with shade under transparent carbon-fibre roofs covered with $75 \%$ black shade netting. Wild grasses were watered daily and were mature (flowering) when used for oviposition and larval performance experiments. A total of 30 species of grass were used in oviposition experiments (Supplement 1). All plants were healthy and without notable insect damage, and were not reused. The species of grass were categorized as either creepers, clusters or bushes based on their architecture (Table 1).

By using large cages, we provided females space to fly around and visually assess plants (Fig. 1A). During oviposition experiments, between 5 and 20 females were present in the outdoor cages, depending on availability. The different species of plants were offered for oviposition in groups of 2 to 7 individuals, placed in a circle on the floor of the cage (Fig. 1A). We endeavoured to provide plants of similar size and shape within experiments, which limited the plant combinations that could be used. Creeping grasses were tied to sticks when tested in combination with grasses that grow in tall clusters. Depending on the number of females that were laying eggs at a given time, the number of plants offered and the number of days they were offered was varied. If the same individual plants were offered on multiple days, eggs were counted and removed daily and their positions within the cage were randomized daily. Eggs were counted blade by blade, noting the size of clutches. These eggs were put into Petri dishes. Any eggs at other locations on the plants or pots were also counted and removed.

Table 1. Summary statistics of preference and performance experiments on the butterfly Melanitis leda on different species of plants. Plant species are sorted by cardinal oviposition preference in terms of the Normalized David score based on counts of clutches, with $\mathrm{N}$ denoting the number of experiments in which a particular plant species was used. For clutch size the number of clutches for which we had egg counts is noted. Egg position reports the number of clutches that were recorded on shoot tips or on withered leaves noting that the availability of the latter was minimal and not quantified. Cardinal larval preference is presented as Normalized David Score for all small $(<2 \mathrm{~cm})$ and large larvae $(>2 \mathrm{~cm})$. See the methods section for more information on how means and s.e. were calculated for larval performance.

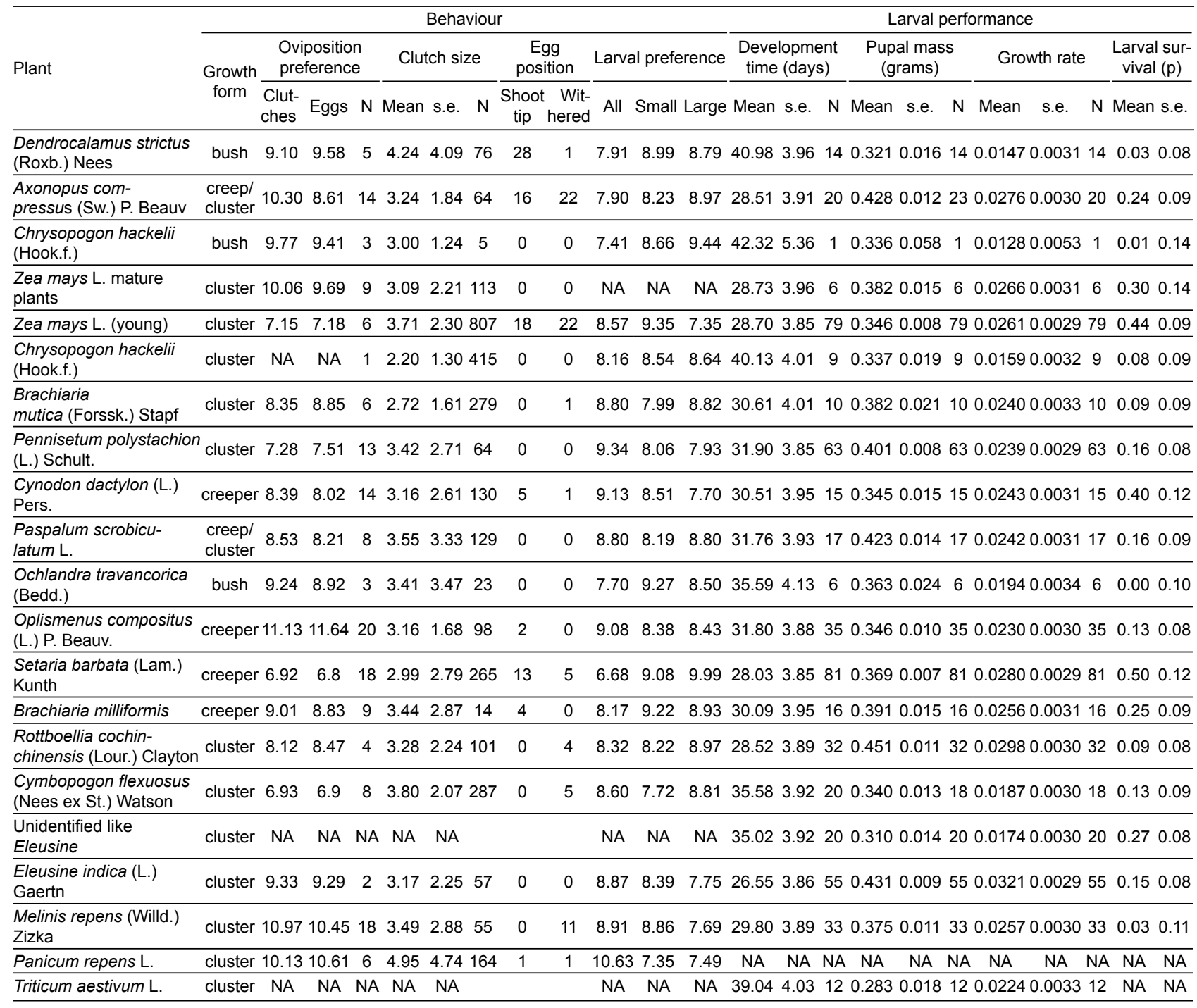



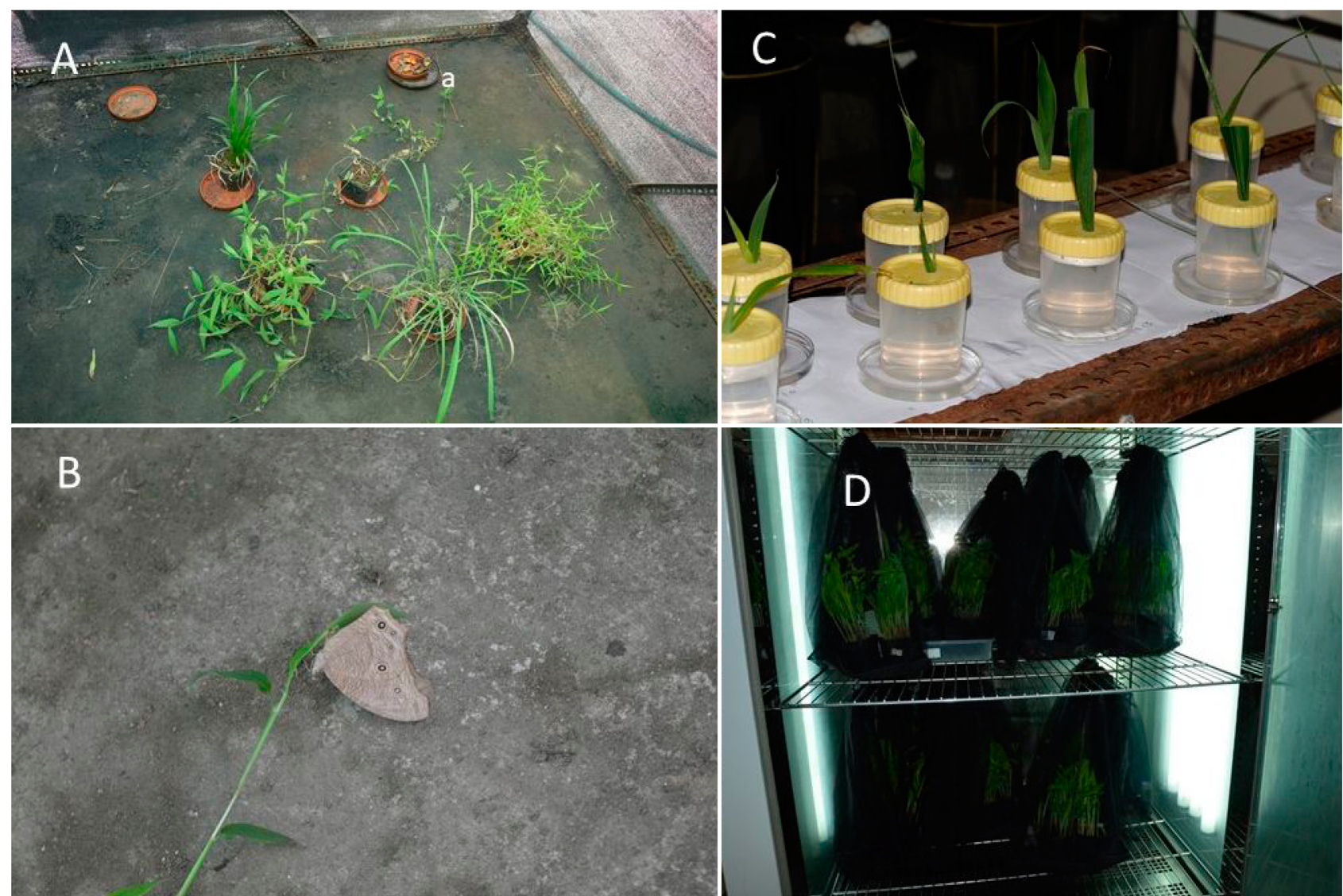

Fig. 1. Photographs of the different experiments. A- Oviposition experiment with five different species of plants; "a" indicates the shoot on which very many eggs were laid (near the plate with mashed banana). B - Female of Melanitis leda laying eggs on the shoot tip indicated in A. C - Larval choice experiment in which in each jar there are shoots or leaves of two species of grass and one larva. D - Incubator with sleeves.

For each test in the oviposition preference experiment, we determined which species had the highest number of egg clutches in each species pair, assuming that the presence of other plant species within an oviposition experiment does not affect the choice between a given two species of plants (see Supplement 1). We further assumed that the presence of eggs on plants does not influence the decision to oviposit in this species (Singer \& Mandracchia, 1982). Since not all the species of plants could be tested in each test, such data treatment was necessary to objectively calculate preference ranks. We then calculated cardinal ranks of oviposition preferences using the R package "steepness", which calculates the cardinal ranks (Normalized David score) from a matrix of paired interactions, where low normalized David scores indicate the more preferred species of plants (Leiva \& De Vries, 2014; R Core Team, 2017). Differences in cardinal ranks among species of grass are larger when preferences are more pronounced, and larger differences result in a steeper preference hierarchy. To be able to compare oviposition preference with larval performance on Axonopus compressus (Sw.) P. Beauv, we averaged the scores for the two growth forms (creeping and erect) to obtain a single species score that could be related to larval performance. We focused on the number of clutches rather than the number of eggs laid, because this might better represent individual oviposition decisions. However, we also performed these analyses based on the number of eggs (see Supplement 1 and 5). We used ANOVA to compare clutch sizes among species of plants and among growth forms, and regression analyses to test if clutch size was predicted by oviposition preference.

\section{Larval choice experiment}

Eggs were obtained from wild-caught females and the larvae reared on a single species of host-plant. To allow larvae to express a choice, stems of cuttings of two species of grass were placed in a hole in the lid of a jar filled with water (Fig. 1C). We replicated plant combinations for which we had larval performance data (see below), with additional trials for plant species combinations that appeared closely matched in terms of larval preference. The jars were placed in a Petri dish with water so that walking insects could not easily enter or leave the jars. Larvae were given six hours to express a choice. Each larva's choice was scored in terms of the grass it had eaten and on which it was present at the end of the experiment. This excludes instances where larvae did not eat. In instances in which both grasses were eaten, this procedure favours plants on which the larva was present (feeding damage was always small compared to leaf surface). We did not have instances where a larva had eaten from one grass only and was present on the grass it had not eaten. To test for any association between larval choice and body size, after the choice was recorded, the length of each larva was measured using a ruler while it was on a leaf.

We used the R package "steepness" (Leiva \& De Vries, 2014; $\mathrm{R}$ Core Team, 2017) to calculate cardinal ranks of larval preferences. We then calculated these ranks separately for small larvae $(4-20 \mathrm{~mm})$ and large larvae $(21-44 \mathrm{~mm})$. Cardinal ranks were simplified to absolute ranks by numbering the species in rank order. We compared the cardinal ranks of the plants among large and small larvae using a General Linear Model (GLM) with 
"Normalized David score" as the dependent variable and "larval size" as a categorical predictor and "plant absolute rank" as a continuous predictor. If there is a stronger preference, cardinal ranks will differ more, resulting in a steeper slope when plotted against absolute ranks. Thus, an interaction between "larval size" and "plant absolute rank" indicates a difference in the strength of the preference expressed among large and small larvae.

\section{Larval survival and development experiment}

To measure performance of larvae on different species of grass, we performed an experiment in a series of four subsequent batches (each one described below) with slightly different methods and in different seasons. On one hand, batches differed as a result of weather influences on plant availability in the wild and probably also plant condition, and on the other hand due to changes in protocol aimed at increasing larval survival. In all batches, larvae were reared on potted plants in nylon sleeves in a climate chamber. Each individual larva was fed only one species of grass throughout, while individual plants were exchanged. Fresh plants were added into sleeves at least a day before the old ones were removed so that larvae could transfer to the fresh ones without being touched by experimenters. As butterfly eggs and space in the growth chamber became available, sleeves were set up over a period of several weeks in each batch. The number of replicates per species of grass in each batch varied for the different species of plants depending on the availability of the grasses and survival of larvae (when many larvae died on a certain grass species, we set up more sleeves for this species in order to be able to measure larval development). The number of sleeves and larvae for each species of plant for each batch is reported in Supplement 3 Table S3.1. These data were pooled and "batch" was used as random effect in statistical analyses to produce comparable estimates of performance measures per plant species across all batches. By including different batches and conditions, the calculated means per plant species should be less biased by for example particular plant growth conditions or plant ages which may have effects on larval performance, and our estimated means thus better represent plant species.

\section{Batch 1}

Eggs were collected from wild-caught females and allowed to hatch in Petri dishes. Ten hatchlings were transferred to potted (0.5 1) plants of one of four species of plants and these were kept in black nylon mesh sleeves in a growth chamber at $21^{\circ} \mathrm{C}$ and $55 \%$ $\mathrm{RH}$ and a $12 \mathrm{~L}: 12 \mathrm{D}$ photoperiod. As food was consumed, new potted plants were added, and old plants were removed. Thus, a sleeve contained 1-3 potted individuals of a single species of plant and up to 10 larvae (as some died or pupated), with sleeves typically touching the foliage (Fig. 1D). Sleeves were inspected daily, and plants were watered on alternate days and replaced as necessary. Pupae were removed and placed singly on tissue paper in transparent jars and kept under the same conditions. One day after pupation, pupae were sexed and weighed to the nearest $0.001 \mathrm{mg}$ (Mettler Toledo JB1603-C/FACT). Pupae were then placed on tissue paper covering the inside of the lid of the up-side-down transparent jar the sides of which were lined with paper so that eclosing butterflies could climb up to allow their wings to unfold. The jars could then easily be inspected daily for eclosions through the transparent bottoms of the jars. This experiment was terminated when ants killed the last remaining larvae and pupae (set up last), so these were not used in the analysis of larval survival, only for larval development. Forty-two pupae were obtained from six sleeves (see Supplement 3 Table S3.1. for details on the number of sleeves per species of plant).

\section{Batch 2}

Similar to batch 1 , but kept at a higher temperature of $24^{\circ} \mathrm{C}$ with $65 \%$ RH. Typically, 10 hatchlings were placed on each potted plant. Plants included common wild grasses, as well as maize seedlings ( $2-4$ weeks old) and more mature maize (2-4 months old). The positions of potted plants in their sleeves in the growth chamber were randomized daily. Every day, pupae and pre-pupae were removed along with a piece of the substrate they were attached to, and the substrate was attached to the lid of the jar using masking tape. Unattached (pre-) pupae were laid on tissue paper. 1-3 days after pupation, pupae were gently removed from their substrate, sexed, weighed (using a Sartorius MSA6.6S-000-DM weighing balance) and placed on the tissue-paper-covered lid of an inverted jar as in experiment 1 . We used 47 sleeves and obtained 73 pupae from this batch (see Supplement 3 Table S3.1. for details on the number of sleeves per species of plant).

\section{Batch 3}

Similar to batch 2, except that: (1) eggs were allowed to hatch on maize seedlings and thus fed on maize for a day before being assigned to different grasses, (2) we added more species of grass including two species of bamboo (Ochlandra travancorica (Bedd.) Gamble and Dendrocalamus strictus (Roxb.) Nees and (3) fewer hatchlings (around 7) were typically put in sleeves in anticipation of higher survival due to the gentler treatment of the hatchlings. Eggs were allowed to hatch on maize seedlings to obtain more information on larval performance by avoiding early mortality due to starvation and handling. We used 66 sleeves and obtained 82 pupae from this batch (see Supplement 3 Table S3.1. for details on the number of sleeves per species of plant).

\section{Batch 4}

Similar to batch 3 , but with newly collected wild grasses that experienced more humid weather (outdoor) before being used to feed larvae in the growth chamber in which the humidity was maintained at about $69 \%$ RH. This was the largest batch with 134 sleeves, which produced 319 pupae (see Supplement 3 Table S3.1. for details on the number of sleeves per species of plant).

To test whether hatchlings could complete their development on bamboos at a high temperature, larvae were reared under warmer conditions on these plants $\left(\mathrm{AC}\right.$ at about $28^{\circ} \mathrm{C}$ during the day), but these were not included in the statistical analyses because these conditions were variable (yielding 44 pupae).

We calculated mean larval survival and its s.e. per species of plant as follows. First we calculated larval survival at the level of sleeves in terms of the proportion of hatchlings that survived to the pupal stage. These proportions were often low $(39 \%$ of sleeves had larval survival between 0 and $10 \%$ ), while most other sleeves (49\%) showed survival percentages between 20 and $70 \%$. Per species of plant means and s.e. were then obtained using a GLMM model (glmer with Gaussian link function in R; Bates et al., 2015) with species of plant as predictor, batch as random effect, and number of hatchling larvae in a sleeve as a weighting factor.

We examined three measures of larval development: development time from egg-hatch to pupation, pupal fresh mass, and growth rate calculated as pupal mass to the power $1 / 3$ divided by development time (based on empirical data on growth of lepidopteran larvae; Tammaru \& Esperk, 2007). To obtain means and s.e. of larval development (development time, pupal mass, growth rate) per species of plant, we used GLMM (glmer with Gaussian link function in R; Bates et al., 2015) with species of plant as predictor and batch as a random effect, and then took the model intercept plus estimates as the estimated mean for each species. 
This procedure makes the means directly comparable despite different conditions in the different batches.

\section{Adult longevity}

Butterflies emerging from batch 3 in the larval performance experiment were kept individually in cylindrical cages of diameter $20 \mathrm{~cm}$ and height $30 \mathrm{~cm}$, made from yellow metal frames and covered with black netting. Seasonal forms may differ in life history traits including longevity (Pijpe et al., 2007). Therefore, butterflies were classified as dry season form, intermediate or wet season form based on eyespots size and background colour pattern. Butterflies were fed a slice of ripe banana covered with moistened cotton wool placed at the top of each cage. Fresh banana was provided every $2-3$ days and cotton wool was rinsed at each feeding and replaced once every two weeks. The cages were kept on shelves in a windowless air-conditioned room maintained at about $24^{\circ} \mathrm{C}$ during the day (cool compared to outdoor conditions) and at ambient temperatures during the night (between 24 and $28^{\circ} \mathrm{C}$ ). A $10 \mathrm{~L}: 14 \mathrm{D}$ cycle was maintained using fluorescent lighting. The positions of the cages was randomized once every two weeks. Dead butterflies were removed daily. Adult longevity results were analysed using Cox models implemented in the survival package (Therneau, 2015) in R, with as predictors pupal mass, phenotype (dry season, intermediate or wet season) and sex.

\section{Correlations between preference and performance}

We used regression models to test for associations between adult and larval preferences, and larval performance at the level of plant species (data summarized in Table 1) in R using the $\mathrm{lm}$ function.

\section{RESULTS}

\section{Oviposition preferences}

A total of 30 species of grass was offered for oviposition in 21 tests, some with egg counts on multiple days so that eggs were counted on 36 days. We counted more than 11,000 eggs in over 3000 clutches and determined the outcome of more than 350 paired interactions among 17 species of plants to calculate the preference hierarchy (Supplement 1 for a summary of paired interactions). Eggs were laid on all the species of plants offered, including creeping grasses, cluster grasses, sedges, and bamboos. Nevertheless, butterflies expressed clear preferences as the normalized David scores differed substantially for the different species of plants (Table 1, Supplement 1). Oviposition preferences were similar when calculated on the basis of batches and numbers of eggs (Table 1). Within a grass species, oviposition preference could differ markedly with plant age (young versus old Zea mays: Table 1), and there was also a slight preference for erect over creeping plants of $A$. compressus (Supplement 1). Only eight eggs were laid on pots in this experiment. Correlation analyses focused on the 17 species of plants for which there were also results for larval performance.

\section{Position of eggs on plants and clutch size}

Eggs were typically laid on the physical underside (not necessarily the abaxial surface) of leaves, singly or in groups. Groups were typically $2-4$ eggs in rows, but occasionally extending to rows of about 8 or forming larger clusters (692 eggs were laid singly, 1376 in pairs, 2130 in triplets, 2016 in quadruplets and 1415 in quintuplets). To our knowledge, no quantitative information on clutch sizes in the wild is available for this species, but the single egg cluster we found in the wild on Setaria barbata (Lam.) Kunth contained 45 eggs, so large clusters are not necessarily an artefact of captivity. However, on one occasion, we observed that immediately upon introduction of the plants, several individuals started laying on the tip of an outlying sprig of Cynodon dactylon (L.) Pers., which the following day was covered with 120 eggs (Fig. 1C). Therefore, large egg clusters may be made up of several clutches in our experiment. We excluded egg-clusters that were likely to consist of more than one clutch from the clutch size analysis (when eggs were heaped, of different sizes and colours, or exceeding 50 eggs). There were differences in mean clutch size recorded on the different species of plants (Anova: $\mathrm{F}_{1,18}=1.61, \mathrm{P}<0.001$ ). However, oviposition preference (based on the number of clutches) was not significantly associated with clutch size (Linear regression: $\mathrm{F}_{1,16}=0.049, \mathrm{P}=0.83$ ). Therefore, clutch size may not simply be a function of "preference" but might involve fine-tuning to particular plant traits. Nevertheless, growth form (cluster, creeper, or bush) was not associated with clutch size (Anova: $\mathrm{F}_{1,18}=0.21, \mathrm{P}=0.89$ ).

Similarly, M. leda did not systematically prefer plants of cluster or creeping growth forms for oviposition (Anova: $\mathrm{F}_{3,14}=0.129, \mathrm{P}=0.94$ ). However, the positions of eggs differed between these two growth forms. Especially on creepers, the penultimate (second most recent) leaf in a shoot was favoured ("shoot tip" in Table 1), often shoots that stick out (illustrated in Fig. 1B). In grasses with a cluster growth form, eggs were laid on leaves both high on the plant and near the ground, but rarely within the cluster. Ovipositing females often showed a preference for the rare withered leaves (brown or yellow) over green leaves in a cluster ("withered leaves" in Table 1). However, the availability of such withered leaves was minimized by periodic pruning, and not measured, so that we cannot make quantitative statements.

\section{Larval choice}

We carried out 391 paired larval choice experiments, 218 using larvae shorter than $2 \mathrm{~cm}$ and 173 with larvae longer than $2 \mathrm{~cm}$. Larvae of $M$. leda accepted all the grasses offered (Supplement 2), but there were clear preferences (Table 1). The ranking differed between small and large larvae, and the trends in ranks were steeper for large larvae (steepness $=0.129)$ than small larvae (steepness $=0.102$; GLM: $\mathrm{N}=18$ plant species, Larval size $\mathrm{T}=2.235, \mathrm{P}=$ 0.033; Larval size * Rank $\mathrm{T}=-2.547, \mathrm{P}=0.016$ ). A steeper ranking means that the larvae differentiated more between the species of plants.

\section{Larval performance}

\section{Survival}

There were large differences in larval survival among the species of plants, ranging between zero and 50\% (Table 1; Fig. 2). Larvae never survived on Panicum repens L., even-though large larvae ate this grass in the larval choice 


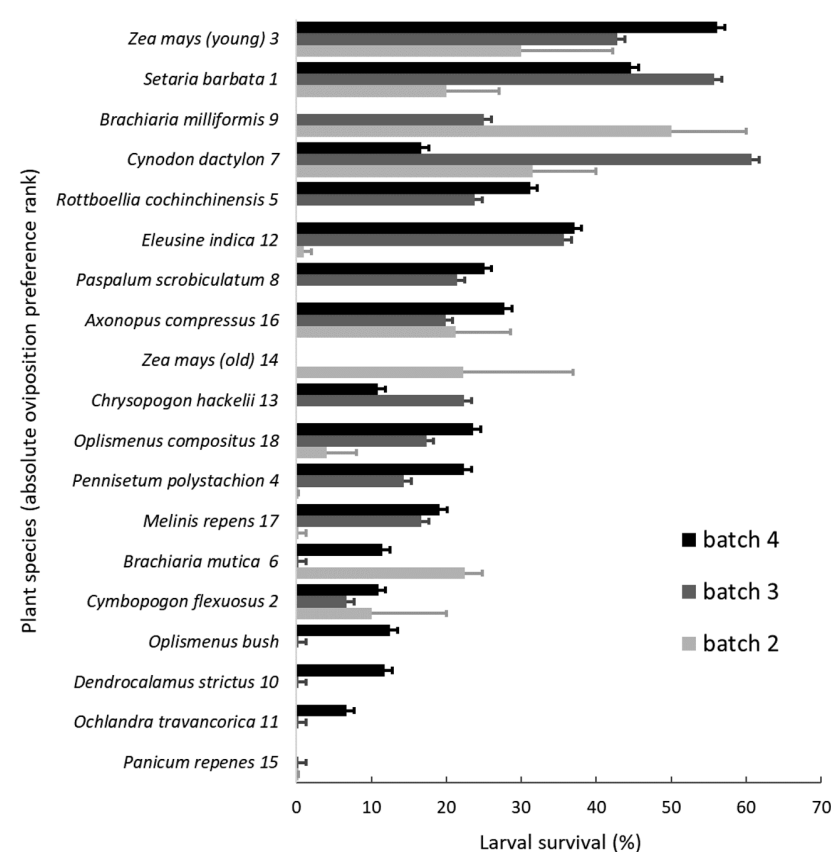

Fig. 2. Average percentage survival of larvae on species of grass in each batch with standard errors with absolute oviposition preference based on number of clutches. When survival was $0 \%$, it was depicted as $0.3 \%$ to distinguish it from missing data.

experiment. Larvae could only be reared on bamboos at high temperatures such as in the laboratory (ca. $28^{\circ} \mathrm{C}, 44$ pupae), but not in a growth chamber at $24^{\circ} \mathrm{C}$, unless hatchlings first fed on other grasses for at least a day (batch 4). Some larvae survived on Brachiaria mutica (Forssk.) Stapf in batches 2 and 4, but not in batch 3. Most mortality appeared to occur during the first week after hatching.

\section{Larval growth}

On the different species of plants, estimated means of larval growth parameters ranged widely (Table 1, Supplement 3 Tables S3.2, S3.3, and S3.4). There were no differences between males and females in development time and pupal mass (Supplement 3). Therefore, sex differences in larval growth were small compared to the differences recorded on the different species of plants and, could be ignored when testing for correlations between preference and performance.

\section{Adult longevity}

The life span of adult $M$. leda butterflies was on average 104 days ( $\mathrm{SD}=70.9, \mathrm{~N}=88$ ) and one butterfly survived for over nine months. Males lived longer than females and the dry-season form lived longer than the wet-season form (Supplement 4). There were no differences between butterflies originating from different species of plants, which was to be expected given the small sample sizes per species of plant. Nevertheless, we found that butterflies lived longer when they were heavier (Cox model clustered by seasonal form: pupal mass exp(coef) $0.038 \mathrm{SE}$ of $\exp$ (coef) $=1.583, \mathrm{P}<0.001 ; \operatorname{sex} \exp ($ coef $)=0.439 \mathrm{SE}$ of $\exp ($ coef $)$ $=0.264, \mathrm{P}<0.001$, likelihood ratio test $=11.4$ on $2 \mathrm{DF}, \mathrm{P}=$ $0.003)$. Thus, the species of host plant does affect adult longevity through its effect on body size. We found no effect

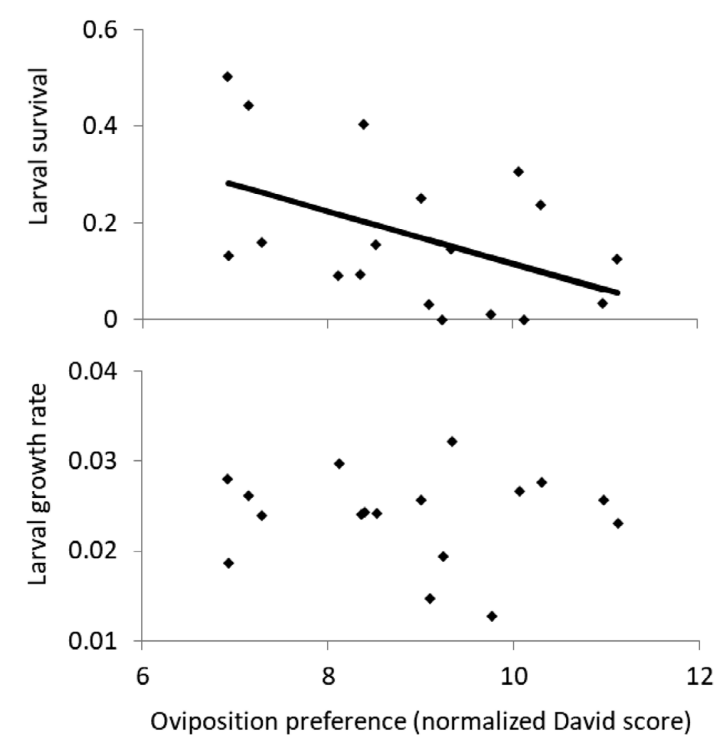

Fig. 3. Relationships between oviposition preferences and larval survival, and oviposition preferences and growth rate in the butterfly $M$. leda. This illustrates that females preferred to lay eggs on species of grass on which larval survival was high (weighted regression: $F_{1,16}=7.14, P=0.017, R^{2}=31 \%$ ), but oviposition preferences were not correlated with average larval growth rate (weighted regression: $F_{1,15}=0.014, P=0.91, R^{2}<1 \%$ ). Lower normalized David scores correspond to more preferred plant species.

of larval development time or growth rate on butterfly life span (Cox model with development time, sex and seasonal form: development time $\mathrm{Z}=0.44, \mathrm{P}=0.66$; sex $\mathrm{Z}=-3.13$, $\mathrm{P}=0.002$; forms $\mathrm{Z}>2.7, \mathrm{P}<0.01$ ).

\section{Correlations between oviposition, feeding preferences, and performance}

Are oviposition preferences reflected in performance?

More clutches were laid on species of plants on which a high proportion of the hatchlings survived to pupate (regression weighted by the number of oviposition experiments in which a particular species of grass was present: $\mathrm{F}_{1,16}=7.14, \mathrm{P}=0.017, \mathrm{R}^{2}=31 \%$; Fig. 3a). However, oviposition preferences were neither correlated with larval growth rate on species of plant (weighted regression: $\mathrm{F}_{1,15}$ $=0.014, \mathrm{P}=0.91, \mathrm{R}^{2}<1 \%$; Fig. $3 \mathrm{~b}$ ) nor with pupal mass (weighted regression: $\mathrm{F}_{1,15}=0.010, \mathrm{P}=0.94, \mathrm{R}^{2}<0.1 \%$ ). Correlations were very similar when calculated using oviposition preferences based on the number of eggs rather than the number of clutches (Supplement 5).

\section{Correlation between larval performance measures}

Larval survival was higher on plants on which larval growth rates were higher (Fig. 4). However, this was only marginally significant (simple regression $\mathrm{F}_{1,17}=4.102, \mathrm{P}=$ 0.058). Notably, low growth rate was associated with low survival, but on species of plants on which larvae could grow fast, survival ranged from low to high.

\section{Does larval choice reflect performance?}

Larval preferences for species of plants were neither predicting larval survival (weighted regression: $\mathrm{T}_{1,16}=$ $-0.935, \mathrm{P}=0.364, \mathrm{R}^{2}=5 \%$ ) nor growth rate on these plants 


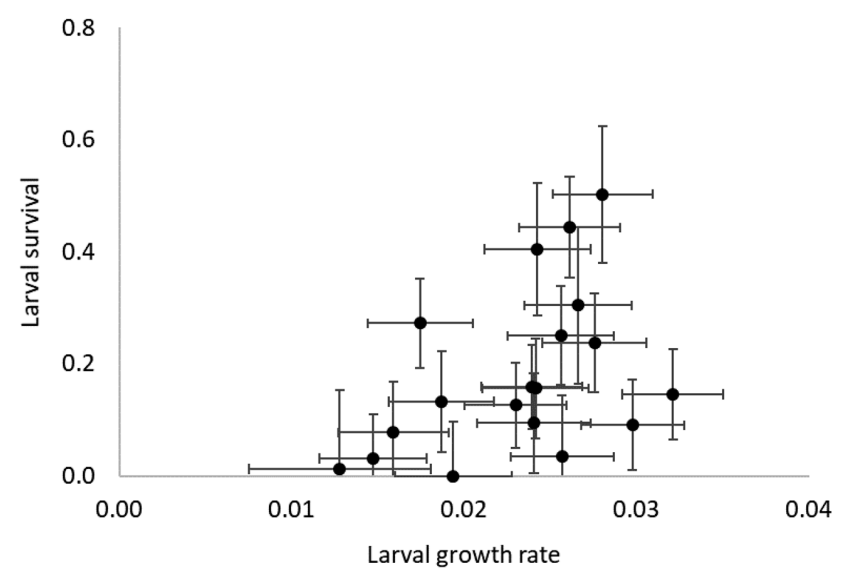

Fig. 4. The relationship between larval survival and growth rate on species of plants, which indicates that the larvae of $M$. leda that on average had a low growth rate also tended to have a low survival rate (simple regression $F_{1,17}=4.102, P=0.058$ ). Data points represent Estimated Marginal Means per plant species with respective s.e. calculated for all experiments.

(weighted regression: $\mathrm{T}_{1,15}=0.268, \mathrm{P}=0.793, \mathrm{R}^{2}<1 \%$ ). Similarly, we found that adult oviposition preferences did not predict larval host-plant preferences $\left(\mathrm{F}_{1,15}=2.267, \mathrm{P}=\right.$ 0.153 ). We also found no trends when the choice of small larvae was tested against survival (expected because most mortality occurred during the first few days; $\mathrm{F}_{1,15}=0.875$, $\mathrm{P}=0.364$ ), and when choice of large larvae was tested against growth rate (expected because most growth occurs in large larvae; $\mathrm{F}_{1,15}=0.2608, \mathrm{P}=0.617$ ).

\section{DISCUSSION}

We performed oviposition and larval-food preference experiments, reared larvae on different species of plants, and measured adult longevity of the tropical grass-feeding butterfly $M$. leda. We show that this species can indeed complete its life cycle on a wide range of species of grass. Nevertheless, it has pronounced oviposition preferences that appear to primarily optimize survival of hatchlings.

Our results show that $M$. leda will lay eggs on a wide variety of grasses (all 30 species tested, including creepers, clusters, sedges, and bamboos), and larvae can complete their development on nearly all grasses provided (18 out of the 19 species tested, including two species of bamboo). This is corroborated by the long list of plant species on which it is recorded in the wild throughout its wide biogeographical range (Larsen, 2005). Therefore, M. leda can use the vast majority of species of grass as host plants in nature. Nevertheless, it is far from indiscriminate.

We found that butterflies laid more eggs on plant species on which their larvae had a higher survival rate. A similar result is reported for the African satyrine butterfly Bicyclus safitza (Nokelainen et al., 2016). However, in contrast to most other studies, we found no correlation between oviposition preference and larval growth rate (Gripenberg et al., 2010; Nokelainen et al., 2016). This indicates that oviposition preferences maximize hatchling survival rather than larval growth rate in this species. Perhaps the lack of correlation between oviposition preference and growth rate is in part due to within plant species variation among individual plants. The individual plants used in the oviposition experiment were necessarily not those fed to larvae in the larval performance experiment. The quality of the grasses will have differed among batches because they grew under varying outdoor conditions (Scheirs et al., 2002), despite daily watering. Such variation is indicated by differences among batches in the relative survival and growth rate among plant species (Fig. 2, Supplement 3), and differences in preference for and performance on maize seedlings versus older maize plants (Table 1). However, by performing oviposition experiments over an extended period (six months) and by using several batches to obtain larval performance data, our data may better represent preference for and performance on different species of plants than if only a single set of plants and conditions was used. Arguably, the wide range in larval survival rates among species of grass that we recorded would exert strong selection on oviposition preferences, which could lead to the observed preference for grass species on which larval survival is high.

Among dicotyledonous plant feeding insects there are also exceptions to the rule that females tend to prefer to oviposit on plants on which their larvae grow best, especially among generalists (Gripenberg et al., 2010; de la Masselière et al., 2017). Such exceptions may not necessarily mean that oviposition preferences are not adaptive (Craig \& Itami, 2008). Oviposition preferences may rather reflect differences in larval survival on different species of plants. This may include early mortality caused by plant defences, for instance as reported in this study, but also mortality due to natural enemies (Damman, 1987; Singer \& Stireman, 2005; Kursar et al., 2006; Singer et al., 2014). For example, M. leda butterflies laid few eggs on Eleusine indica (L.) Gaertn, even though both larval survival and growth rate were high on this species of grass. However, this species has narrow, dark green leaves on which the light green with yellow larvae of $M$. leda are conspicuous and would thus probably suffer a high predation rate in the field. On the other hand, it may well be that there is selection to prefer $S$. barbata because $M$. leda larvae appear to be highly cryptic on it. Indeed, $S$. barbata is regarded as an important host plant of $M$. leda in the wild in this region (S. Kalesh, pers. comm.). Nevertheless, other grasses are also used in the wild and these may confer other fitness advantages. Furthermore, apparent suboptimal oviposition preferences can be due to, for example, time constraints and sensory limitations (Craig \& Itami, 2008; Sahoo \& Kodandaramaiah, 2018).

Host-plant generalists may use plants with a wide variety of plant architectures that each select for particular clutch sizes and positioning of eggs on the plants. Therefore, host-plant generalists might be expected to show plastic oviposition behaviour. Indeed, we found that in M. leda, clutch size differed between species of plants, and the positioning of eggs varied with plant architecture. That eggs were typically laid on the penultimate leaves of creeping grasses may be explained by nutrition and by avoidance of 
natural enemies. Eggs laid on second leaves will hatch on a tender young leaf, which is probably more nutritious than both the youngest leaf and older leaves (Barbehenn et al., 2017). Furthermore, walking predators may be less likely to find prey at the shoot tips of complex plants since there are many such tips, compared to other plant parts (Casas $\&$ Djemai, 2002). The frequent choice of (rare) withered leaves that larvae cannot feed on may be explained by lower predation pressure on such leaves. Laying on withered leaves would then be similar to laying eggs away from a plant (Wiklund, 1984; Bergman, 2000; Lindman et al., 2013). This indicates that butterflies first assess the overall plant quality and then oviposit on sites most suitable for hatchlings, or where natural enemies may least expect to find eggs. Overall, these butterflies appear to adapt their fine-scale oviposition behaviour to plant traits, a plasticity that may be expected especially in a generalist species, because generalists utilize plants with a wide variety of traits.

The expectation is that larvae will survive best on plants on which they have high growth rates (Williams, 1999). However, this relationship appeared weak in our data and was only marginally significant. This may be explained by the conditions during the first few days being particularly critical for larval survival, while growth rate differences are more important in later larval development. Plants on which hatchling survival is low may have defences against small larvae (e.g. hairs or tough cuticle) that large larvae can overcome. These more defended plants may be more nutritious so that larvae can achieve a high growth rate on them once they outgrow the plant's defences. In our sample, this may particularly be the case for B. mutica (Fig. 2 ). In this species, stems and leaves are covered with long fine hairs, which probably impede movements of hatchlings (Karban \& Takabayashi, 2019). Perhaps hatchlings can only survive on $B$. mutica if they hatch on the youngest leaves that are not yet so hairy. Some larvae of the second batch (hatchlings) and of the fourth (1 day old larvae) survived on $B$. mutica, but none of the third (1 day old larvae). The $B$. mutica plants used for the third batch were more mature and had experienced more dry-season conditions (despite daily watering) and may thus have been less suitable for the hatchlings. This indicates that individual plants of a species and leaves on an individual plant on which eggs are laid may affect first instar larval survival. The few larvae that did survive on $B$. mutica had a high growth rate. Such combinations of low early survival and high growth rate may contribute to a weak correlation across plant species between larval survival and larval growth.

Similar to ovipositing adults, larvae are also expected to prefer species of plants on which they perform better (Wiklund, 1975). However, we found no correlations between larval choice and larval survival or growth. Large larvae may have displayed a steeper preference, because they were better able to make a choice rather than accept the first plant encountered.

Larval host plants may affect insect longevity through their effect on body size (Shirai, 1995). In our study, sample sizes per species of plant were too low to effectively compare adult longevity among butterflies reared on different species, or even to use averages per plant to explore correlations. Nevertheless, large butterflies lived longer, suggesting that there is selection to prefer plant species on which $M$. leda tends to produce large pupae. However, such a preference was not recorded in our cross-species regression analysis of ovipostion preference and pupal mass.

Future studies may address more detailed questions on the oviposition preferences of $M$. leda butterflies and the consequences of variation in leaf quality among individual plants within species, and individual leaves within plants. The limited availability of large cages resulted in us using groups of females in oviposition experiments in order to include more females and obtain a larger number of eggs than would be possible using single females. In the absence of such practical constraints, we would have gathered oviposition preference data from individual butterflies rather than groups. Further work will be needed to investigate individual variation in oviposition preferences, the possibility that these preferences might be learned or induced, and the potential influences of oviposition and larval feeding on responses to the different hosts (Friberg \& Wiklund, 2016; Hopkins, 1916; Schäpers et al., 2017).

\section{CONCLUSIONS}

Melanitis leda is a host-plant generalist that will lay eggs on a wide variety of grasses, and their larvae can complete their development on nearly all of them. Nevertheless, it is far from indiscriminate because it shows strong oviposition preferences, behavioural responses to plant architecture, and larval food preferences. Females preferred to lay eggs on species of grass on which larvae had high survival rates, but oviposition preference was not correlated with larval growth rate. Larval survival and growth rate on the different species of plants were only weakly correlated with each other. Furthermore, larval choice was not correlated with performance or oviposition preferences. Larger body size was associated with long life. This study shows that this species of butterfly, which feeds on a wide variety of grasses, is nevertheless selective, and especially prefers plants on which larval survival is high.

ACKNOWLEDGEMENTS. We thank H. Mayekar for advice on rearing $M$. leda and sexing pupae, and building the shelters in which we constructed the large cages. We are grateful to J. Vijaykumar and O. Vignesh for help with growing plants, rearing larvae, and sexing and weighing pupae. B. Parthasarathy helped with counting eggs, and K. Balasubramaniam and B. Parthasarathy provided statistical advice. We are grateful to S. Kalesh and N. Ravi for plant identification and advice, and R. Sahoo for comments on the manuscript. We thank the reviewers who provided comments that greatly improved the manuscript. This work was funded through intra-mural funds from IISER Thiruvananthapuram and a grant from the Department of Science and Technology, Government of India to U. Kodandaramaiah (INSPIRE Faculty Award number DST/INSPIRE/04/2013/000476). The data are available upon request.

AUTHOR CONTRIBUTIONS. FM, UK and SH designed the study. Most data were collected by FM and some by SH. Data 
analyses were performed by FM. Manuscript writing was headed by FM with input from UK and SH. We have no conflicts of interest to report.

\section{REFERENCES}

BARBEHENN R.V. \& Bernays E.A. 1992: Relative nutritional quality of $\mathrm{C} 3$ and $\mathrm{C} 4$ grasses for a graminivorous lepidopteran, Paratrytone melane (Hesperiidae). - Oecologia 92: 97-103.

Barbehenn R.V., Kapila M., Kileen S. \& Nusbaum C.P. 2017: Acquiring nutrients from tree leaves: effects of leaf maturity and development type on a generalist caterpillar. - Oecologia 184: 59-73.

Bates D., Maechler M., Bolker B. \& Walker S. 2015: Fitting linear mixed-effects models using lme4. - J. Stat. Softw. 67: $1-48$.

BEAVER R.A. 1979: Host specificity of temperate and tropical animals. - Nature 281: 139-141.

Bergman K.O. 2000: Oviposition, host plant choice and survival of a grass feeding butterfly, the Woodland Brown (Lopinga achine) (Nymphalidae: Satyrinae). - J. Res. Lepid. 35: 9-21.

Bernays E.A., Singer M.S. \& Rodrigues D. 2004: Foraging in nature: foraging efficiency and attentiveness in caterpillars with different diet breadths. - Ecol. Entomol. 29: 389-397.

BRAKeFIELD P.M. 1987: Tropical dry and wet season polyphenism in the butterfly Melanitis leda (Satyrinae): Phenotypic plasticity and climatic correlates. - Biol. J. Linn. Soc. 31: 175-191.

CASAs J. \& DJemai I. 2002: Canopy architecture and multitrophic interactions. In Tscharntke T. \& Hawkins B.A. (eds): Multitrophic Level Interactions. Cambridge University Press, Cambridge, pp. 174-196.

Cayssials V. \& Rodríguez C. 2013: Functional traits of grasses growing in open and shaded habitats. - Evol. Ecol. 27: 393 407.

CHEW F.S. 1980: Foodplant preferences of Pieris caterpillars (Lepidoptera). - Oecologia 46: 347-353.

Craig T.P. \& Itami J.K. 2008: Evolution of preference and performance relationships. In Tilmon K.J. (ed.): Specialization, Speciation, and Radiation. The Evolutionary Biology of Herbivorous Insects. University of California Press, Berkeley, CA, pp. 20-28.

DAMMAN H. 1987: Leaf quality and enemy avoidance by the larvae of a pyralid moth. - Ecology 68: 88-97.

Davis R.B., Õunap E., Javoiš J., Gerhold P. \& Tammaru T. 2013: Degree of specialization is related to body size in herbivorous insects: a phylogenetic confirmation. - Evolution 67: 583589.

De la Masselière C.M., Facon B., Hafsi A. \& Duyck P.-F. 2017: Diet breadth modulates preference - performance relationships in a phytophagous insect community. - Sci. Rep. 7: 16934, 9 pp.

Edwards E.J., Osborne C.P., Strömberg C.A., Smith S.A. \& C4 Grasses Consortium 2010: The origins of $\mathrm{C} 4$ grasslands: integrating evolutionary and ecosystem science. - Science 328: 587-591.

EHRLICH P.R. \& RAVEN P.H. 1964: Butterflies and plants: a study in coevolution. - Evolution 18: 586-608.

Faeth S. \& Bultman T.L. 2002: Endophytic fungi and interactions among host plants, herbivores, and natural enemies. In Tscharntke T. \& Hawkins B.A. (eds): Multitrophic Level Interactions. University of Cambridge, Cambridge, $282 \mathrm{pp}$.

FriBerg M. \& WIKLUND C. 2009: Host plant preference and performance of the sibling species of butterflies Leptidea sinapis and Leptidea reali: a test of the trade-off hypothesis for food specialisation. - Oecologia 159: 127-137.
Friberg M. \& WiKLUND C. 2016: Butterflies and plants: preference/performance studies in relation to plant size and the use of intact plants vs. cuttings. - Entomol. Exp. Appl. 160: 201-208.

Gamberale-Stille G., SöDerlind L., Janz N. \& Nylin S. 2014: Host plant choice in the comma butterfly: larval choosiness may ameliorate effects of indiscriminate oviposition. - Insect Sci. 21: 499-506.

García-Barros E. \& Fartmann T. 2009: Butterfly oviposition: sites, behaviour and modes. In Settele J., Shreeve T., Konvicka M. \& Van Dyck H. (eds): Ecology of Butterflies in Europe. Cambridge University Press, Cambridge, pp. 29-42.

GiLBert L.E. 1979: Development of theory in the analysis of insect-plant interaction. In Horn D.J., Mitchell R.D. \& Stairs G.R. (eds): Analysis of Ecological Systems. Ohio University Press, Columbus, pp. 210-240.

Godfray H.C.J. 1986: Clutch size in a leaf-mining fly (Pegomya nigritarsis, Anthomyiidae). - Ecol. Entomol. 11: 75-81.

Gripenberg S., Mayhew P.J., Parnell M. \& Roslin T. 2010: A meta-analysis of preference-performance relationships in phytophagous insects. - Ecol. Lett. 13: 383-393.

Hardy T.N., Clay K. \& Hammond A.M. 1985: Fall armyworm (Lepidoptera: Noctuidae): a laboratory bioassay and larval preference study for the fungal endophyte of perennial ryegrass. - J. Econ. Entomol. 78: 571-575.

HartLey S.E. \& DeGabriel J.L. 2016: The ecology of herbivoreinduced silicon defences in grasses. - Func. Ecol. 30: 13111322.

HopkINS A.D. 1916: Economic Investigations of the Scolytid Bark and Timber Beetles of North America. U.S. Department of Agriculture Program of work for 1917, $353 \mathrm{pp}$.

JAENIKE J. 1978: Optimal oviposition behavior in phytophagous insects. - Theor. Popul. Biol. 14: 350-356.

Kalesh S. \& Prakash S.K. 2007: Additions to larval host plants of butterflies of the Western Ghats, Kerala, Southern India (Rhopalocera, Lepidoptera). Part 1. - J. Bombay Nat. Hist. Soc. 104: 235-238.

Kalesh S. \& Prakash S.K. 2009: Early stages of the Travancore Evening Brown Parantirrhoea marshalli Wood-Mason (Satyrinae, Nymphalidae, Lepidoptera), an endemic butterfly from the southern Western Ghats, India. - J. Bombay Nat. Hist. Soc. 106: 142-148.

KARBAN R. \& TAKABAYASH J. 2019: Chewing and other cues induce grass spines that protect meristems. - Arthr.-Plant Interact. 13: 541-550.

Karlsson B. \& WiKLund C. 1985: Egg weight variation in relation to egg mortality and starvation endurance of newly hatched larvae in some satyrid butterflies. - Ecol. Entomol. 10: 205-211.

Kunte K. 2012: Butterflies of Peninsular India. Universities Press, Hyderabad, 272 pp.

Kursar T.A., Wolfe B., Epps M.J. \& Coley P.D. 2006: Food quality, competition, and parasitism influence feeding preference in a neotropical lepidopteran. — Ecology 87: 3058-3069.

LARSEN T.B. 2005: Butterflies of West Africa. Apollo Books, Vester Skerninge, $900 \mathrm{pp}$.

Leiva D. \& De VRIes H. 2014: Steepness: Testing Steepness of Dominance Hierarchies. R Package Ver. 0.2-2. URL: https:// CRAN.R-project.org/package $=$ steepness.

Leniaud L., Audiot P., Bourguet D., Frérot B., Genestier G., Lee S.F., Malausa T., Le Pallec A.-H., Souqual M.-C. \& Ponsard S. 2006: Genetic structure of European and Mediterranean maize borer populations on several wild and cultivated host plants. - Entomol. Exp. Appl. 120: 51-62.

Lindman L., Johansson B., GotThard K. \& Tammaru T. 2013: Host plant relationships of an endangered butterfly, Lopinga 
achine (Lepidoptera: Nymphalidae) in northern Europe. $-J$. Insect Conserv. 17: 375-383.

MatTson W.J. 1980: Herbivory in relation to plant nitrogen content. - Annu. Rev. Ecol. Syst. 11: 119-161.

Moore G.J. 1986: Host plant discrimination in tropical satyrine butterflies. - Oecologia 70: 592-595.

Nokelainen O., Ripley B.S., Bergen E., Osborne C.P. \& BrakeFIELD P.M. 2016: Preference for C4 shade grasses increases hatchling performance in the butterfly, Bicyclus safitza. Ecol. Evol. 6: 5246-5255.

Peña C. \& Wahlberg N. 2008: Prehistorical climate change increased diversification of a group of butterflies. - Biol. Lett. 4: $274-278$.

Pijpe J., Brakefield P.M. \& ZwaAn B.J. 2007: Phenotypic plasticity of starvation resistance in the butterfly Bicyclus anynana. —Evol. Ecol. 21: 589-600.

R Core Team 2017: R: A Language and Environment for Statistical Computing. R Foundation for Statistical Computing, Vienna, Austria.

Renwick J.A.A. \& Chew F.S. 1994: Oviposition behavior in Lepidoptera. - Annu. Rev. Entomol. 39: 377-400.

SAHOo R.K. \& Kodandaramaiah U. 2018: Local host plant abundance explains negative association between larval performance and female oviposition preference in a butterfly. - Biol. J. Linn. Soc. 125: 333-343.

Sahoo R.K., Warren A.D., Collins S.C. \& Kodandaramaiah U. 2017: Host plant change and paleoclimatic events explain diversification shifts in skipper butterflies (Family: Hesperiidae). - BMC Evol. Biol. 17: 174, 9 pp.

SChÄPERS A., Nylin S., CARLsSon M.A. \& JANZ N. 2016: Specialist and generalist oviposition strategies in butterflies: maternal care or precocious young? - Oecologia 180: 335-343.

Schäpers A., Petrén H., Wheat C.W., Wiklund C. \& Friberg M. 2017: Female fecundity variation affects reproducibility of experiments on host plant preference and acceptance in a phytophagous insect. - Proc. R. Soc. Lond. (B) 284: 20162643, 9 pp.

Scheirs J., De Bruyn L. \& Verhagen R. 2000: Optimization of adult performance determines host choice in a grass miner. Proc. R. Soc. Lond. (B) 267: 2065-2069.

Scheirs J., De Bruyn L. \& Verhagen R. 2002: Seasonal changes in leaf nutritional quality influence grass miner performance. - Ecol. Entomol. 27: 84-93.

SHIRAI Y. 1995: Longevity, flight ability and reproductive performance of the diamondback moth Plutella xylostella (L.) (Lepidoptera: Yponomeutidae), related to adult body size. - Res. Popul. Ecol. 37: 269-277.

Showler A.T. \& Moran P.J. 2014: Associations between host plant concentrations of selected biochemical nutrients and Mexican rice borer, Eoreuma loftini (Dyar) (Lepidoptera: Crambidae), infestation. - Entomol. Exp. Appl. 151: 135-143.

Simpson S.J. \& Raubenheimer D. 2012: The Nature of Nutrition: A Unifying Framework from Animal Adaptation to Human Obesity. Princeton University Press, Princeton, NJ, 256 pp.

SINGER M.C. 1986: The definition and measurement of oviposition preference in plant-feeding insects. In Miller J.R. \& Miller T.A. (eds): Insect-Plant Interactions. Springer, New York, pp. $65-94$.

SINGER M.C. 2004: Measurement, correlates, and importance of oviposition preference in the life of checkerspots. In Ehrlich P.R. \& Hanski I. (eds): On the Wings of Checkerspots: A Model System for Population Biology. Oxford University Press, Oxford, pp. 113-137.
Singer M.C. \& MANDRACChIA J. 1982: On the failure of two butterfly species to respond to the presence of conspecific eggs prior to oviposition. - Ecol. Entomol. 7: 327-330.

Singer M.S. \& StiREMAN J.O. 2005: The tri-trophic niche concept and adaptive radiation of phytophagous insects. - Ecol. Lett. 8: $1247-1255$.

Singer M.S., Lichter-Marck I.H., Farkas T.E., Aaron E., WhitNEY K.D. \& MOONEY K.A. 2014: Herbivore diet breadth mediates the cascading effects of carnivores in food webs. - Proc. Natl. Acad. Sci. (Biol.) 111: 9521-9526.

Soler R., Pineda A., Li Y., Ponzio C., Loon J.J.A. van, WeldEGERGIS B.T. \& DiCKE M. 2012: Neonates know better than their mothers when selecting a host plant. _ Oikos 121: 1923-1934.

Solofondranohatra C.L., Vorontsova M.S., Hackel J., Besnard G., Cable S., Williams J., Jeannoda V. \& Lehmann C.E.R. 2018: Grass functional traits differentiate forest and savanna in the Madagascar central highlands. - Front. Ecol. Evol. 6: $184,8 \mathrm{pp}$.

Southwood T.R.E. \& Kennedy C.E.J. 1983: Trees as islands. Oikos 41: 359-371.

Stuhldreher G. \& Fartmann T. 2015: Oviposition-site preferences of a declining butterfly Erebia medusa (Lepidoptera: Satyrinae) in nutrient-poor grasslands. - Eur. J. Entomol. 112: 493-499.

TAMmaru T. \& Esperk T. 2007: Growth allometry of immature insects: larvae do not grow exponentially. - Funct. Ecol. 21: 1099-1105.

Therneau T. 2015: A Package for Survival Analysis in S. Version 2.38. URL: https://CRAN.R-project.org/package $=$ survival.

Thomas J.A. 1984: The conservation of butterflies in temperate countries: past efforts and lessons for the future. In VaneWright R.I. \& Ackery P.R. (eds): Biology of Butterflies. Symposium of the Royal Entomological Society of London No. 11. Academic Press, London. pp. 333-353.

THOMPSON J.N. 1988: Evolutionary ecology of the relationship between oviposition preference and performance of offspring in phytophagous insects. - Entomol. Exp. Appl. 47: 3-14.

TsCharntKe T. 1988: Variability of the grass Phragmites australis in relation to the behaviour and mortality of the gall-inducing midge Giraudiella inclusa (Diptera, Cecidomyiidae). - Oecologia 76: 504-512.

Van Bergen E., Barlow H.S., Brattström O., Griffiths H., Kodandaramaiah U., Osborne C.P. \& Brakefield P.M. 2016: The stable isotope ecology of mycalesine butterflies: implications for plant-insect co-evolution. - Funct. Ecol. 30: 19361946.

Vialatte A., Bailey R.I., Vasseur C., Matocq A., Gossner M.M., Everhart D., Vitrac X., Belhadj A., Ernoult A. \& Prinzing A. 2010: Phylogenetic isolation of host trees affects assembly of local Heteroptera communities. - Proc. R. Soc. (B) 277: 2227-2236.

Whitcomb R.F., Kramer J., CoAn M.E. \& Hicks A.L. 1987: Ecology and evolution of leafhopper-grass host relationships in North American grasslands. In Harris K.F. (ed.): Current Topics in Vector Research. Vol. 4. Springer, New York, NY, pp. 121-178.

WIKLUND C. 1975: The evolutionary relationship between adult oviposition preferences and larval host plant range in Papilio machaon L. - Oecologia 18: 185-197.

WIKLUND C. 1984: Egg-laying patterns in butterflies in relation to their phenology and the visual apparency and abundance of their host plants. - Oecologia 63: 23-29.

WILLIAMS I.S. 1999: Slow-growth, high-mortality - a general hypothesis, or is it? - Ecol. Entomol. 24: 490-495. 
WiLlis K.J. \& McELwaIn J.C. 2002: The Evolution of Plants. Oxford University Press, Oxford, 378 pp.

Zalucki M.P., Clarke A.R. \& Malcolm S.B. 2002: Ecology and behavior of first instar larval Lepidoptera. - Annu. Rev. Entomol. 47: 361-393.

Received July 13, 2019; revised and accepted December 6, 2019

Published online January 13, 2020

Supplement 1. Oviposition preferences for potential host plants of $M$. leda.

Table S1.1. Summary of the results of oviposition experiments summarized as dyadic interactions based on the number of clutches (see Methods for details). The number in each cell below the diagonal denotes the number of occasions in which the plant in the row was preferred over the one in the column heading, while above the diagonal the plant species in the column heading was preferred. The latter are "reversals" of the preference hierarchy in which on average a less preferred plant is chosen. Column names are abbreviations of the row names.

\begin{tabular}{|c|c|c|c|c|c|c|c|c|c|c|c|c|c|c|c|c|c|c|c|}
\hline \multirow[b]{2}{*}{ Loosers } & \multicolumn{19}{|c|}{ Winners } \\
\hline & S. $b$ & C. $f$. & $\begin{array}{l}\text { Z. } m \text {. } \\
\text { young }\end{array}$ & P. p. & R. C. & & . C. $d$. & P. s. & B. $m$. & D. s. & O. $t$. & E. $i$ & A. C. & $\begin{array}{l}\text { A. C. } \\
\text { crawl }\end{array}$ & $\begin{array}{c}\text { Unid. } \\
\text { bo. }\end{array}$ & $\begin{array}{l}\text { Z. } m \text {. } \\
\text { old }\end{array}$ & P. $r$. & M. r. & O. $c$. \\
\hline Setaria barbata & $x$ & 3 & 8 & 4 & 1 & 0 & 0 & 0 & 1 & 1 & 0 & 0 & 0 & 0 & 0 & 0 & 0 & 0 & 0 \\
\hline Cymbopogon flexuosus & 1 & $x$ & 0 & 2 & 0 & 0 & 0 & 0 & 0 & 0 & 0 & 0 & 2 & 0 & 0 & 0 & 0 & 0 & 0 \\
\hline Zea mays (young) & 0 & 0 & $x$ & 0 & 0 & 0 & 0 & 0 & 0 & 0 & 0 & 0 & 0 & 0 & 0 & 0 & 0 & 0 & 0 \\
\hline Pennisetum polystachion & 7 & 2 & 7 & $x$ & 1 & 0 & 2 & 0 & 0 & 0 & 0 & 0 & 0 & 0 & 0 & 0 & 0 & 0 & 0 \\
\hline Rottboellia cochinchinensis & 1 & 2 & 0 & 0 & $x$ & 0 & 0 & 0 & 1 & 0 & 0 & 0 & 0 & 1 & 0 & 0 & 0 & 0 & 0 \\
\hline Brachiaria mutica & 2 & 1 & 0 & 0 & 0 & $x$ & 0 & 2 & 0 & 0 & 0 & 0 & 0 & 0 & 0 & 0 & 0 & 0 & 0 \\
\hline Cynodon dactylon & 10 & 0 & 7 & 6 & 0 & 0 & $x$ & 0 & 1 & 0 & 0 & 0 & 0 & 0 & 0 & 0 & 0 & 0 & 1 \\
\hline Paspalum scrobiculatum & 0 & 1 & 0 & 2 & 0 & 2 & 0 & $x$ & 0 & 1 & 0 & 0 & 2 & 0 & 0 & 0 & 0 & 0 & 0 \\
\hline Brachiaria milliformis & 2 & 2 & 0 & 0 & 1 & 0 & 1 & 0 & $x$ & 0 & 0 & 1 & 1 & 0 & 0 & 0 & 1 & 0 & 0 \\
\hline Dendrocalamus strictus & 0 & 2 & 0 & 2 & 0 & 0 & 0 & 2 & 0 & $x$ & 1 & 0 & 2 & 0 & 0 & 0 & 0 & 0 & 0 \\
\hline Ochlandra travancorica & 1 & 0 & 0 & 0 & 0 & 0 & 0 & 2 & 0 & 2 & $x$ & 0 & 0 & 0 & 0 & 0 & 0 & 0 & 0 \\
\hline Eleusine indica & 0 & 0 & 0 & 0 & 0 & 0 & 0 & 0 & 1 & 0 & 0 & $x$ & 2 & 0 & 0 & 0 & 0 & 0 & 0 \\
\hline Axonopus compressus & 4 & 2 & 0 & 3 & 1 & 4 & 3 & 4 & 1 & 0 & 0 & 0 & $x$ & 1 & 0 & 1 & 0 & 1 & 1 \\
\hline A. c. crawl & 6 & 2 & 0 & 2 & 2 & 4 & 3 & 4 & 2 & 0 & 0 & 0 & 5 & $x$ & 0 & 2 & 0 & 1 & 1 \\
\hline Unid. bo. & 1 & 0 & 0 & 0 & 0 & 0 & 0 & 2 & 0 & 2 & 2 & 0 & 1 & 0 & $x$ & 0 & 0 & 0 & 0 \\
\hline Zea mays (old) & 9 & 3 & 5 & 8 & 3 & 0 & 8 & 0 & 1 & 0 & 0 & 0 & 0 & 0 & 0 & $x$ & 0 & 2 & 2 \\
\hline Panicum repens & 3 & 3 & 0 & 1 & 1 & 1 & 0 & 0 & 0 & 0 & 0 & 0 & 1 & 1 & 0 & 0 & $x$ & 1 & 0 \\
\hline Melinis repens & 14 & 2 & 7 & 8 & 0 & 5 & 10 & 4 & 0 & 0 & 0 & 0 & 5 & 3 & 0 & 2 & 1 & $x$ & 2 \\
\hline Oplismenus compositus & 11 & 3 & 7 & 8 & 2 & 1 & 12 & 0 & 1 & 0 & 0 & 0 & 1 & 1 & 0 & 4 & 1 & 6 & $x$ \\
\hline
\end{tabular}

Table S1.2. Results of oviposition experiments summarized as dyadic interactions based on the number of eggs. The number in each cell below the diagonal denotes the number of occasions in which the plant in the row heading was preferred over the one in the column, while above the diagonal the plant species in the column heading was preferred. The latter are "reversals" to the preference hierarchy. Column names are abbreviations of the row names.

\begin{tabular}{|c|c|c|c|c|c|c|c|c|c|c|c|c|c|c|c|c|c|c|c|}
\hline \multirow[b]{2}{*}{ Loosers } & \multicolumn{19}{|c|}{ Winners } \\
\hline & S. b & C. f. & $\begin{array}{l}\text { Z. m. } \\
\text { young }\end{array}$ & P. p. & R.c. & B. $\mathrm{m}$ & n. C. d. & P. s. & B. m. & D. s. & o. t. & E. i. & A. C & $\begin{array}{l}\text { A. c. } \\
\text { crawl }\end{array}$ & $\begin{array}{l}\text { Unid. } \\
\text { bo. }\end{array}$ & $\begin{array}{l}\text { Z. m. } \\
\text { old }\end{array}$ & P. r. & M. r. & O. c. \\
\hline Setaria barbata & $x$ & 4 & 6 & 5 & 0 & 0 & 1 & 0 & 1 & 0 & 0 & 0 & 1 & 0 & 0 & 0 & 0 & 0 & 0 \\
\hline Cymbopogon flexuosus & 1 & $x$ & 0 & 2 & 0 & 0 & 0 & 1 & 0 & 0 & 0 & 0 & 2 & 0 & 0 & 0 & 0 & 0 & 0 \\
\hline Zea mays (young) & 0 & 0 & $x$ & 0 & 0 & 0 & 0 & 0 & 0 & 0 & 0 & 0 & 0 & 0 & 0 & 1 & 0 & 0 & 0 \\
\hline Pennisetum polystachion & 5 & 2 & 6 & $x$ & 2 & 1 & 0 & 0 & 1 & 0 & 0 & 0 & 0 & 0 & 0 & 0 & 1 & 0 & 0 \\
\hline Rottboellia cochinchinensis & 2 & 2 & 0 & 0 & $x$ & 0 & 0 & 0 & 1 & 0 & 0 & 0 & 0 & 1 & 0 & 1 & 0 & 0 & 0 \\
\hline Brachiaria mutica & 3 & 4 & 0 & 0 & 0 & $x$ & 1 & 1 & 0 & 0 & 0 & 0 & 1 & 0 & 0 & 1 & 1 & 1 & 0 \\
\hline Cynodon dactylon & 9 & 0 & 6 & 7 & 0 & 0 & $x$ & 0 & 0 & 0 & 0 & 0 & 0 & 0 & 0 & 0 & 0 & 0 & 1 \\
\hline Paspalum scrobiculatum & 0 & 1 & 0 & 2 & 0 & 1 & 0 & $x$ & 0 & 1 & 1 & 0 & 2 & 0 & 0 & 0 & 0 & 0 & 0 \\
\hline Brachiaria milliformis & 2 & 1 & 0 & 0 & 1 & 0 & 1 & 2 & $x$ & 0 & 0 & 1 & 2 & 0 & 0 & 0 & 0 & 1 & 1 \\
\hline Dendrocalamus strictus & 0 & 2 & 0 & 2 & 0 & 0 & 0 & 3 & 0 & $x$ & 1 & 0 & 2 & 0 & 0 & 0 & 0 & 0 & 0 \\
\hline Ochlandra travancorica & 0 & 0 & 0 & 0 & 0 & 0 & 0 & 1 & 0 & 1 & $x$ & 0 & 0 & 0 & 0 & 0 & 0 & 0 & 0 \\
\hline Eleusine indica & 0 & 0 & 0 & 0 & 0 & 1 & 0 & 0 & 0 & 0 & 0 & $x$ & 2 & 0 & 0 & 0 & 0 & 0 & 0 \\
\hline Axonopus compressus & 4 & 2 & 0 & 3 & 1 & 3 & 3 & 4 & 1 & 0 & 0 & 0 & $x$ & 2 & 0 & 1 & 0 & 1 & 2 \\
\hline A. c. crawl & 6 & 2 & 0 & 2 & 2 & 2 & 3 & 4 & 2 & 0 & 0 & 0 & 6 & $x$ & 0 & 2 & 0 & 2 & 2 \\
\hline Unid. bo. & 0 & 0 & 0 & 0 & 0 & 0 & 0 & 2 & 0 & 3 & 3 & 0 & 0 & 0 & $x$ & 0 & 0 & 0 & 0 \\
\hline Zea mays (old) & 7 & 3 & 4 & 7 & 2 & 0 & 5 & 0 & 0 & 0 & 0 & 0 & 0 & 0 & 0 & $x$ & 0 & 3 & 2 \\
\hline Panicum repens & 5 & 3 & 0 & 1 & 1 & 1 & 0 & 0 & 3 & 0 & 0 & 0 & 1 & 1 & 0 & 1 & $x$ & 2 & 1 \\
\hline Melinis repens & 13 & 2 & 6 & 7 & 0 & 3 & 9 & 4 & 2 & 0 & 0 & 0 & 5 & 1 & 0 & 0 & 2 & $x$ & 2 \\
\hline Oplismenus compositus & 13 & 5 & 6 & 9 & 2 & 3 & 12 & 0 & 3 & 0 & 0 & 0 & 3 & 2 & 0 & 5 & 2 & 8 & $x$ \\
\hline
\end{tabular}




\section{Supplement 2.}

Table S2. Results of the larval food choice experiment. The number in each cell below the diagonal denotes the number of occasions on which the plant in the row heading was preferred over the one in the heading, while above the diagonal the plant species in the column heading was preferred. The latter are "reversals" of the preference hierarchy. Column names are abbreviations of the row names.

\begin{tabular}{lcccccccccccccccccccc}
\hline & S. b. O. bush & O. t. & A. c. & D. s. & C. h. & B. m. R. c. Z. m. C. f. & P. s. & B. m. E. i. & M. r. O. c. C. d. P. p. P. r. \\
\hline Setaria barbata & $\mathrm{x}$ & 1 & 0 & 0 & 3 & 0 & 0 & 2 & 0 & 3 & 0 & 4 & 0 & 0 & 3 & 1 & 1 & 0 \\
Oplismenus bush & 1 & $\mathrm{x}$ & 1 & 2 & 0 & 0 & 3 & 0 & 0 & 0 & 0 & 0 & 0 & 0 & 0 & 1 & 0 & 0 \\
Ochlandra travancorica & 0 & 0 & $\mathrm{x}$ & 3 & 0 & 0 & 0 & 3 & 1 & 0 & 0 & 0 & 0 & 2 & 0 & 1 & 0 & 0 \\
Axonopus compressus & 4 & 0 & 2 & $\mathrm{x}$ & 0 & 1 & 4 & 3 & 2 & 0 & 0 & 4 & 0 & 0 & 5 & 3 & 2 & 0 \\
Dendrocalamus strictus & 0 & 1 & 1 & 1 & $\mathrm{x}$ & 2 & 0 & 1 & 2 & 2 & 3 & 1 & 2 & 0 & 0 & 2 & 0 & 0 \\
Chrysopogon hackelii & 2 & 1 & 1 & 0 & 3 & $\mathrm{x}$ & 0 & 1 & 0 & 6 & 0 & 1 & 2 & 2 & 0 & 0 & 1 & 1 \\
Brachiaria milliformis & 1 & 3 & 1 & 0 & 2 & 2 & $\mathrm{x}$ & 0 & 0 & 0 & 0 & 0 & 2 & 0 & 1 & 1 & 1 & 0 \\
Rottboellia cochinchinensis & 5 & 0 & 0 & 2 & 1 & 1 & 3 & $\mathrm{x}$ & 4 & 0 & 4 & 2 & 2 & 2 & 1 & 1 & 0 & 0 \\
Zea mays (young) & 4 & 1 & 1 & 5 & 1 & 1 & 0 & 1 & $\mathrm{x}$ & 0 & 0 & 0 & 1 & 0 & 0 & 2 & 2 & 0 \\
Cymbopogon flexuosus & 2 & 0 & 0 & 2 & 0 & 5 & 0 & 4 & 2 & $\mathrm{x}$ & 0 & 2 & 0 & 0 & 3 & 0 & 1 & 0 \\
Paspalum scrobiculatum & 0 & 0 & 1 & 2 & 3 & 1 & 0 & 0 & 2 & 0 & $\mathrm{x}$ & 0 & 3 & 1 & 1 & 0 & 3 & 0 \\
Brachiaria mutica & 3 & 0 & 0 & 4 & 3 & 1 & 0 & 1 & 0 & 3 & 1 & $\mathrm{x}$ & 0 & 3 & 6 & 0 & 7 & 0 \\
Eleusine indica & 2 & 0 & 0 & 4 & 3 & 3 & 1 & 6 & 0 & 0 & 2 & 1 & $\mathrm{x}$ & 1 & 0 & 0 & 2 & 0 \\
Melinis repens & 0 & 0 & 0 & 2 & 2 & 0 & 0 & 0 & 1 & 1 & 3 & 2 & 2 & $\mathrm{x}$ & 0 & 0 & 1 & 1 \\
Oplismenus compositus & 6 & 4 & 1 & 1 & 1 & 1 & 3 & 2 & 1 & 2 & 2 & 1 & 2 & 0 & $\mathrm{x}$ & 0 & 1 & 0 \\
Cynodon dactylon & 2 & 3 & 3 & 0 & 2 & 2 & 6 & 3 & 0 & 0 & 3 & 0 & 0 & 0 & 3 & $\mathrm{x}$ & 0 & 0 \\
Pennisetum polystachion & 5 & 1 & 0 & 4 & 0 & 1 & 2 & 3 & 1 & 4 & 0 & 5 & 1 & 0 & 6 & 1 & $\mathrm{x}$ & 1 \\
Panicum repens & 0 & 0 & 0 & 3 & 1 & 0 & 0 & 1 & 1 & 0 & 3 & 3 & 3 & 8 & 0 & 0 & 2 & $\mathrm{x}$ \\
\hline
\end{tabular}

Supplement 3. Results for the different batches in the performance experiment.

Table S3.1. Percentage larval survival from hatching to pupation, where $\mathrm{N}$ hatch $=$ the total number of hatchlings tested, and $\mathrm{N}$ the number of sleeves per plant per batch. Note that for batch 1 we have no results for larval survival.

\begin{tabular}{|c|c|c|c|c|c|c|c|c|c|c|}
\hline & \multirow{2}{*}{$\mathrm{N}$ hatch } & \multicolumn{3}{|c|}{ Batch 2} & \multicolumn{3}{|c|}{ Batch 3} & \multicolumn{3}{|c|}{ Batch 4} \\
\hline & & $\mathrm{N}$ & Average & StDev & $\mathrm{N}$ & Average & StDev & $\mathrm{N}$ & Average & StDev \\
\hline Dendrocalamus strictus & 89 & & & & 1 & 0.0 & & 5 & 11.8 & 23.6 \\
\hline Axonopus compressus & 117 & 6 & 21.2 & 18.1 & 6 & 19.9 & 13.1 & 3 & 27.8 & 25.5 \\
\hline Oplismenus bush & 24 & & & & 2 & 0.0 & 0.0 & 1 & 12.5 & \\
\hline Zea mays (old) & 26 & 3 & 22.2 & 25.5 & & & & & & \\
\hline Zea mays (young) & 104 & 5 & 30.0 & 27.4 & 2 & 42.9 & 20.2 & 5 & 56.2 & 26.7 \\
\hline Chrysopogon hackelii & 92 & & & & 3 & 22.4 & 30.5 & 4 & 10.8 & 15.7 \\
\hline Brachiaria mutica & 112 & 3 & 22.4 & 4.2 & 7 & 0.0 & 0.0 & 2 & 11.5 & 1.4 \\
\hline Pennisetum polystachion & 275 & 6 & 0.0 & 0.0 & 7 & 14.3 & 24.7 & 20 & 22.4 & 22.6 \\
\hline Cynodon dactylon & 40 & 2 & 31.5 & 12.0 & 2 & 60.7 & 15.2 & 1 & 16.7 & \\
\hline Paspalum scrobiculatum & 100 & & & & 2 & 21.4 & 30.3 & 12 & 25.1 & 31.6 \\
\hline Ochlandra travancorica & 71 & & & & 2 & 0.0 & 0.0 & 5 & 6.7 & 14.9 \\
\hline Oplismenus compositus & 231 & 5 & 4.0 & 8.9 & 5 & 17.3 & 20.5 & 14 & 23.6 & 22.2 \\
\hline Setaria barbata & 162 & 4 & 20.0 & 14.1 & 4 & 55.7 & 44.0 & 14 & 44.7 & 27.5 \\
\hline Brachiaria milliformis & 38 & 3 & 50.0 & 17.3 & 2 & 25.0 & 35.4 & & & \\
\hline R. cochinchinensis & 103 & & & & 4 & 23.8 & 31.6 & 11 & 31.2 & 17.2 \\
\hline Cymbopogon flexuosus & 166 & 2 & 10.0 & 14.1 & 6 & 6.7 & 16.3 & 6 & 10.9 & 15.1 \\
\hline Unid, tough Eleusine & 91 & & & & 1 & 30.0 & & 5 & 22.3 & 10.5 \\
\hline Eleusine indica & 175 & 2 & 0.0 & 0.0 & 5 & 35.7 & 33.5 & 15 & 37.1 & 31.8 \\
\hline Melinis repens & 167 & 2 & 0.0 & 0.0 & 2 & 16.7 & 0.0 & 10 & 19.1 & 18.6 \\
\hline Panicum repens & 51 & 3 & 0.0 & 0.0 & 3 & 0.0 & 0.0 & & & \\
\hline
\end{tabular}


Table S3.2. Larval development time from egg hatch to pupation for $\mathrm{N}$ individual females and males per batch, with extremes per batch marked in bold. See Methods for further details.

\begin{tabular}{|c|c|c|c|c|c|c|c|}
\hline \multicolumn{8}{|c|}{ Larval development time (days) } \\
\hline \multirow{2}{*}{ Batch } & \multirow{2}{*}{ Plant } & \multicolumn{3}{|c|}{ Females } & \multicolumn{3}{|c|}{ Males } \\
\hline & & $\mathrm{N}$ & Average & StdDev & $\mathrm{N}$ & Average & StdDev \\
\hline \multirow[t]{4}{*}{1} & Zea mays (young) & 5 & 47.4 & 5.9 & 4 & 37.0 & 3.6 \\
\hline & Pennisetum polystachion & 5 & 44.2 & 1.8 & 1 & 44.0 & \\
\hline & Setaria barbata & 9 & 43.3 & 2.7 & 4 & 45.5 & 4.1 \\
\hline & Triticum aestivum & 6 & 53.0 & 4.6 & 6 & 54.0 & 3.3 \\
\hline \multirow[t]{9}{*}{2} & Axonopus compressus & 10 & 27.2 & 1.3 & 3 & 31.3 & 3.2 \\
\hline & Zea mays (old) & 5 & 29.8 & 1.5 & 1 & 27.0 & \\
\hline & Zea mays (young) & 7 & 27.1 & 1.9 & 6 & 27.8 & 1.9 \\
\hline & Brachiaria mutica & 4 & 29.0 & 7.6 & 3 & 29.7 & 5.5 \\
\hline & Cynodon dactylon & 1 & 35.0 & & 6 & 31.7 & 2.7 \\
\hline & Oplismenus compositus & 1 & 38.0 & & 1 & 35.0 & \\
\hline & Setaria barbata & 3 & 29.3 & 2.5 & 5 & 31.6 & 3.7 \\
\hline & Brachiaria milliformis & 7 & 30.7 & 2.4 & 7 & 29.6 & 5.5 \\
\hline & Cymbopogon flexuosus & 1 & 31.0 & & 1 & 22.0 & \\
\hline \multirow[t]{13}{*}{3} & Axonopus compressus & 3 & 24.3 & 0.6 & 2 & 26.0 & 1.4 \\
\hline & Zea mays (young) & 4 & 25.5 & 1.3 & 1 & 28.0 & \\
\hline & Chrysopogon hackelii & 2 & 28.5 & 0.7 & 2 & 38.0 & 1.4 \\
\hline & Pennisetum polystachion & 4 & 34.8 & 5.1 & 3 & 32.7 & 3.1 \\
\hline & Cynodon dactylon & 3 & 26.7 & 1.5 & 4 & 26.5 & 2.5 \\
\hline & Paspalum scrobiculatum & 1 & 28.0 & & 2 & 33.5 & 2.1 \\
\hline & Oplismenus compositus & 1 & 31.0 & & 4 & 35.3 & 5.9 \\
\hline & Setaria barbata & 7 & 24.4 & 2.4 & 8 & 23.1 & 2.3 \\
\hline & Brachiaria milliformis & 1 & 27.0 & & 1 & 27.0 & \\
\hline & Rottboellia cochinchinensis & 1 & 27.0 & & 4 & 24.0 & 1.4 \\
\hline & Cymbopogon flexuosus & 1 & 30.0 & & 2 & 39.0 & 1.4 \\
\hline & Eleusine indica & 6 & 23.7 & 2.1 & 6 & 21.7 & 1.5 \\
\hline & Melinis repens & 3 & 30.5 & 4.9 & 2 & 26.5 & 0.7 \\
\hline \multirow[t]{17}{*}{4} & Dendrocalamus strictus & 7 & 38.1 & 3.8 & 7 & 31.6 & 2.2 \\
\hline & Axonopus compressus & 3 & 23.3 & 2.5 & 2 & 22.5 & 0.7 \\
\hline & Oplismenus bush & 1 & 35.0 & & & & \\
\hline & Zea mays (young) & 32 & 23.0 & 4.3 & 20 & 22.9 & 4.1 \\
\hline & Chrysopogon hackelii & 3 & 36.0 & 3.6 & 2 & 37.5 & 19.1 \\
\hline & Brachiaria mutica & 2 & 26.5 & 0.7 & 1 & 26.0 & \\
\hline & Pennisetum polystachion & 25 & 24.8 & 3.3 & 25 & 24.2 & 3.5 \\
\hline & Cynodon dactylon & & & & 1 & 21.0 & \\
\hline & Paspalum scrobiculatum & 7 & 23.3 & 3.0 & 7 & 25.0 & 3.1 \\
\hline & Ochlandra travancorica & 2 & 33.5 & 2.1 & 4 & 27.8 & 1.3 \\
\hline & Oplismenus compositus & 12 & 22.6 & 3.6 & 16 & 23.7 & 3.8 \\
\hline & Setaria barbata & 21 & 20.7 & 2.2 & 24 & 20.0 & 2.6 \\
\hline & Rottboellia cochinchinensis & 10 & 21.6 & 4.0 & 17 & 21.4 & 4.0 \\
\hline & Cymbopogon flexuosus & 4 & 31.3 & 6.7 & 11 & 28.0 & 4.0 \\
\hline & Unid, tough small Eleusine & 10 & 28.4 & 2.8 & 10 & 27.0 & 2.5 \\
\hline & Eleusine indica & 22 & 20.5 & 2.4 & 21 & 18.7 & 2.5 \\
\hline & Melinis repens & 10 & 23.2 & 3.3 & 18 & 21.8 & 2.9 \\
\hline
\end{tabular}


Table S3.3. Average pupal mass of $\mathrm{N}$ individual females and males for each batch.

\begin{tabular}{|c|c|c|c|c|c|c|c|}
\hline \multicolumn{8}{|c|}{ Pupal mass $(\mathrm{g})$} \\
\hline \multirow{2}{*}{ Batch } & \multirow{2}{*}{ Plant } & \multicolumn{3}{|c|}{ Females } & \multicolumn{3}{|c|}{ Males } \\
\hline & & $\mathrm{N}$ & Average & StdDev & $\mathrm{N}$ & Average & StdDev \\
\hline \multirow[t]{4}{*}{1} & Zea mays (young) & 5 & 0.415 & 0.039 & 4 & 0.354 & 0.054 \\
\hline & Pennisetum polystachion & 5 & 0.376 & 0.033 & 1 & 0.337 & \\
\hline & Setaria barbata & 9 & 0.358 & 0.059 & 4 & 0.301 & 0.043 \\
\hline & Triticum aestivum & 6 & 0.262 & 0.037 & 6 & 0.300 & 0.021 \\
\hline \multirow[t]{9}{*}{2} & Axonopus compressus & 10 & 0.435 & 0.035 & 3 & 0.504 & 0.047 \\
\hline & Zea mays (old) & 5 & 0.378 & 0.070 & 1 & 0.325 & \\
\hline & Zea mays (young) & 7 & 0.383 & 0.017 & 6 & 0.360 & 0.057 \\
\hline & Brachiaria mutica & 4 & 0.471 & 0.063 & 3 & 0.396 & 0.042 \\
\hline & Cynodon dactylon & 1 & 0.291 & & 6 & 0.308 & 0.038 \\
\hline & Oplismenus compositus & 1 & 0.316 & & 1 & 0.316 & \\
\hline & Setaria barbata & 3 & 0.402 & 0.092 & 5 & 0.300 & 0.083 \\
\hline & Brachiaria milliformis & 7 & 0.397 & 0.033 & 7 & 0.388 & 0.028 \\
\hline & Cymbopogon flexuosus & 1 & 0.466 & & 1 & 0.487 & \\
\hline \multirow[t]{13}{*}{3} & Axonopus compressus & 3 & 0.434 & 0.013 & 2 & 0.427 & 0.060 \\
\hline & Zea mays (young) & 4 & 0.360 & 0.063 & 1 & 0.232 & \\
\hline & Chrysopogon hackelii & 2 & 0.378 & 0.061 & 2 & 0.343 & 0.123 \\
\hline & Pennisetum polystachion & 4 & 0.476 & 0.075 & 3 & 0.429 & 0.084 \\
\hline & Cynodon dactylon & 3 & 0.349 & 0.022 & 4 & 0.414 & 0.043 \\
\hline & Paspalum scrobiculatum & 1 & 0.387 & & 2 & 0.391 & 0.025 \\
\hline & Oplismenus compositus & 1 & 0.379 & & 4 & 0.371 & 0.058 \\
\hline & Setaria barbata & 7 & 0.388 & 0.055 & 8 & 0.362 & 0.040 \\
\hline & Brachiaria milliformis & 1 & 0.370 & & 1 & 0.433 & \\
\hline & Rottboellia cochinchinensis & 1 & 0.455 & & 4 & 0.481 & 0.079 \\
\hline & Cymbopogon flexuosus & 1 & 0.353 & & 2 & 0.286 & 0.043 \\
\hline & Eleusine indica & 6 & 0.451 & 0.051 & 6 & 0.410 & 0.059 \\
\hline & Melinis repens & 3 & 0.335 & 0.098 & 2 & 0.283 & 0.100 \\
\hline \multirow[t]{17}{*}{4} & Dendrocalamus strictus & 7 & 0.330 & 0.055 & 7 & 0.310 & 0.074 \\
\hline & Axonopus compressus & 3 & 0.411 & 0.024 & 2 & 0.328 & 0.030 \\
\hline & Oplismenus bush & 1 & 0.337 & & & & \\
\hline & Zea mays (young) & 32 & 0.358 & 0.066 & 20 & 0.315 & 0.030 \\
\hline & Chrysopogon hackelii & 3 & 0.308 & 0.120 & 2 & 0.348 & 0.105 \\
\hline & Brachiaria mutica & 2 & 0.349 & 0.025 & 1 & 0.244 & \\
\hline & Pennisetum polystachion & 25 & 0.415 & 0.052 & 25 & 0.385 & 0.049 \\
\hline & Cynodon dactylon & & & & 1 & 0.378 & \\
\hline & Paspalum scrobiculatum & 7 & 0.456 & 0.054 & 7 & 0.408 & 0.067 \\
\hline & Ochlandra travancorica & 2 & 0.372 & 0.056 & 4 & 0.357 & 0.040 \\
\hline & Oplismenus compositus & 12 & 0.376 & 0.041 & 16 & 0.321 & 0.070 \\
\hline & Setaria barbata & 21 & 0.398 & 0.039 & 24 & 0.369 & 0.050 \\
\hline & Rottboellia cochinchinensis & 10 & 0.476 & 0.054 & 17 & 0.432 & 0.070 \\
\hline & Cymbopogon flexuosus & 4 & 0.368 & 0.099 & 11 & 0.316 & 0.046 \\
\hline & Unid, tough small Eleusine & 10 & 0.316 & 0.043 & 10 & 0.306 & 0.063 \\
\hline & Eleusine indica & 22 & 0.452 & 0.026 & 21 & 0.413 & 0.051 \\
\hline & Melinis repens & 10 & 0.393 & 0.029 & 18 & 0.384 & 0.039 \\
\hline
\end{tabular}


Table S3.4. Average larval growth rate from egg hatch to pupation of $\mathrm{N}$ individual females and males for each batch (pupal mass to the power $1 / 3$ divided by development time).

\begin{tabular}{|c|c|c|c|c|c|c|c|}
\hline \multicolumn{8}{|c|}{ Growth rate } \\
\hline \multirow{2}{*}{ Batch } & & \multicolumn{3}{|c|}{ Females } & \multicolumn{3}{|c|}{ Males } \\
\hline & & $\mathrm{N}$ & Average & StdDev & $\mathrm{N}$ & Average & StdDev \\
\hline \multirow[t]{4}{*}{1} & Zea mays (young) & 5 & 0.016 & 0.002 & 4 & 0.019 & 0.002 \\
\hline & Pennisetum polystachion & 5 & 0.016 & 0.001 & 1 & 0.016 & \\
\hline & Setaria barbata & 9 & 0.016 & 0.001 & 4 & 0.015 & 0.002 \\
\hline & Triticum aestivum & 6 & 0.012 & 0.001 & 6 & 0.011 & 0.005 \\
\hline \multirow[t]{9}{*}{2} & Axonopus compressus & 10 & 0.028 & 0.001 & 3 & 0.026 & 0.003 \\
\hline & Zea mays (old) & 5 & 0.024 & 0.002 & 1 & 0.025 & \\
\hline & Zea mays (young) & 7 & 0.027 & 0.002 & 6 & 0.026 & 0.002 \\
\hline & Brachiaria mutica & 4 & 0.028 & 0.004 & 3 & 0.025 & 0.005 \\
\hline & Cynodon dactylon & 1 & 0.019 & & 6 & 0.021 & 0.001 \\
\hline & Oplismenus compositus & 1 & 0.018 & & 1 & 0.019 & \\
\hline & Setaria barbata & 3 & 0.025 & 0.003 & 5 & 0.021 & 0.004 \\
\hline & Brachiaria milliformis & 7 & 0.024 & 0.002 & 7 & 0.025 & 0.004 \\
\hline & Cymbopogon flexuosus & 1 & 0.025 & & 1 & 0.036 & \\
\hline \multirow[t]{13}{*}{3} & Axonopus compressus & 3 & 0.031 & 0.001 & 2 & 0.029 & 0.003 \\
\hline & Zea mays (young) & 4 & 0.028 & 0.002 & 1 & 0.022 & \#DIV/0! \\
\hline & Chrysopogon hackelii & 2 & 0.025 & 0.002 & 2 & 0.018 & 0.002 \\
\hline & Pennisetum polystachion & 4 & 0.023 & 0.004 & 3 & 0.023 & 0.003 \\
\hline & Cynodon dactylon & 3 & 0.026 & 0.001 & 4 & 0.028 & 0.003 \\
\hline & Paspalum scrobiculatum & 1 & 0.026 & & 2 & 0.022 & 0.001 \\
\hline & Oplismenus compositus & 1 & 0.023 & & 4 & 0.021 & 0.002 \\
\hline & Setaria barbata & 7 & 0.030 & 0.004 & 8 & 0.031 & 0.004 \\
\hline & Brachiaria milliformis & 1 & 0.027 & & 1 & 0.028 & \\
\hline & Rottboellia cochinchinensis & 1 & 0.028 & & 4 & 0.033 & 0.001 \\
\hline & Cymbopogon flexuosus & 1 & 0.024 & & 2 & 0.017 & 0.000 \\
\hline & Eleusine indica & 6 & 0.033 & 0.004 & 6 & 0.034 & 0.003 \\
\hline & Melinis repens & 3 & 0.024 & 0.001 & 2 & 0.025 & 0.002 \\
\hline \multirow[t]{17}{*}{4} & Dendrocalamus strictus & 7 & 0.018 & 0.002 & 7 & 0.022 & 0.003 \\
\hline & Axonopus compressus & 3 & 0.032 & 0.003 & 2 & 0.031 & 0.000 \\
\hline & Oplismenus bushs & 1 & 0.020 & & & & \\
\hline & Zea mays (young) & 32 & 0.031 & 0.007 & 20 & 0.030 & 0.005 \\
\hline & Chrysopogon hackelii & 3 & 0.019 & 0.004 & 2 & 0.021 & 0.009 \\
\hline & Brachiaria mutica & 2 & 0.027 & 0.001 & 1 & 0.024 & \\
\hline & Pennisetum polystachion & 25 & 0.031 & 0.005 & 25 & 0.031 & 0.004 \\
\hline & Cynodon dactylon & & & & 1 & 0.034 & \\
\hline & Paspalum scrobiculatum & 7 & 0.033 & 0.004 & 7 & 0.030 & 0.005 \\
\hline & Ochlandra travancorica & 2 & 0.021 & 0.000 & 4 & 0.026 & 0.001 \\
\hline & Oplismenus compositus & 12 & 0.033 & 0.005 & 16 & 0.030 & 0.006 \\
\hline & Setaria barbata & 21 & 0.036 & 0.004 & 24 & 0.036 & 0.005 \\
\hline & Rottboellia cochinchinensis & 10 & 0.037 & 0.006 & 17 & 0.037 & 0.007 \\
\hline & Cymbopogon flexuosus & 4 & 0.023 & 0.004 & 11 & 0.025 & 0.003 \\
\hline & Unid, tough small Eleusine & 10 & 0.024 & 0.002 & 10 & 0.025 & 0.001 \\
\hline & Eleusine indica & 22 & 0.038 & 0.005 & 21 & 0.040 & 0.005 \\
\hline & Melinis repens & 10 & 0.032 & 0.004 & 18 & 0.034 & 0.004 \\
\hline
\end{tabular}

Supplement 4. Adult longevity of $M$. leda butterflies reared on different species of grass. Males lived longer than females, and dry season forms (DSF) lived longer than wet season forms (WSF).

Table S4. Results of Cox model of adult life span of $M$. leda butterflies with sex and seasonal form as predictors. Males are compared with females and intermediate and wet season forms with dry season forms.

\begin{tabular}{lccccc}
\hline & Coef & exp(coef) & SE(coef) & Z & $P$ \\
\hline Sex = male & -0.749 & 0.473 & 0.261 & 2.87 & 0.004 \\
Form = intermediate & 1.250 & 3.491 & 0.330 & 3.79 & 0.000 \\
Form = wet season & 0.685 & 1.984 & 0.289 & 2.37 & 0.018 \\
\hline
\end{tabular}

Likelihood ratio test $=22$ on $3 \mathrm{df}, \mathrm{P}<0.001, \mathrm{~N}=76$. 


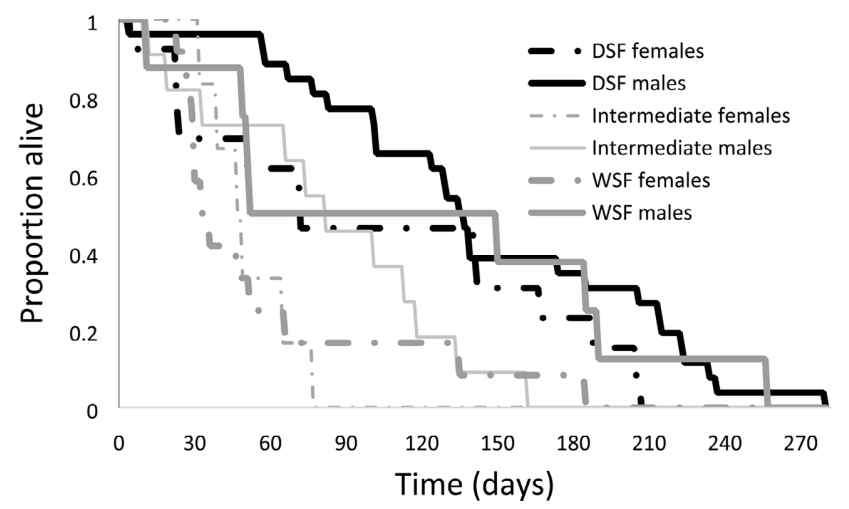

Fig. S4. Proportional survival over time of $M$. leda butterflies kept indivdiually in captivity. DSF - dry season form, WSF - wet season form.

\section{Supplement 5.}

Table S5. The correlation between two measures of oviposition preference (based on number of eggs and clutches) and for each measure correlations with performance. The two measures of oviposition preference are highly correlated and yield similar results: only larval survival is significantly correlated with oviposition preference.

\begin{tabular}{|c|c|c|c|c|c|c|c|}
\hline \multirow{2}{*}{$\begin{array}{l}\text { Predictor } \\
\text { Response }\end{array}$} & \multicolumn{4}{|c|}{ Normalized David score based on egg numbers } & \multicolumn{3}{|c|}{ Normalized David score clutches } \\
\hline & d.f. & $\mathrm{F}$ & $p$ & R2 & $\mathrm{F}$ & $\mathrm{p}$ & R2 \\
\hline Norm DS Clutch & 16 & 87.64 & $<0.001$ & $84 \%$ & & & \\
\hline Clutch size & 16 & 0.25 & 0.62 & $2 \%$ & 0.054 & 0.82 & $<1 \%$ \\
\hline Larval survival & 16 & 10.4 & 0.005 & $39 \%$ & 7.14 & 0.017 & $35 \%$ \\
\hline Larval growth rate & 15 & 0.4 & 0.54 & $3 \%$ & 0.014 & 0.91 & $<1 \%$ \\
\hline Pupal mass & 15 & 0.38 & 0.55 & $2 \%$ & 0.01 & 0.94 & $<1 \%$ \\
\hline Larval preference & 15 & 2.34 & 0.15 & $13 \%$ & 2.27 & 0.15 & $13 \%$ \\
\hline
\end{tabular}

